\title{
Fruit cuticular waxes as a source of biologically active triterpenoids
}

\author{
Anna Szakiel · Cezary Pączkowski • \\ Flora Pensec $\cdot$ Christophe Bertsch
}

Received: 15 December 2011 / Accepted: 4 June 2012/Published online: 26 June 2012

(C) The Author(s) 2012. This article is published with open access at Springerlink.com

\begin{abstract}
The health benefits associated with a diet rich in fruit and vegetables include reduction of the risk of chronic diseases such as cardiovascular disease, diabetes and cancer, that are becoming prevalent in the aging human population. Triterpenoids, polycyclic compounds derived from the linear hydrocarbon squalene, are widely distributed in edible and medicinal plants and are an integral part of the human diet. As an important group of phytochemicals that exert numerous biological effects and display various pharmacological activities, triterpenoids are being evaluated for use in new functional foods, drugs, cosmetics and healthcare products. Screening plant material in the search for triterpenoid-rich plant tissues has identified fruit peel and especially fruit cuticular waxes as promising and highly available sources. The chemical composition, abundance and biological activities of triterpenoids occurring in cuticular waxes of some economically important fruits, like apple, grape berry, olive, tomato and others, are described in
\end{abstract}

\footnotetext{
A. Szakiel $(\square) \cdot$ C. Pączkowski

Department of Plant Biochemistry, Faculty of Biology, University of Warsaw, ul. Miecznikowa 1, 02-096

Warszawa, Poland

e-mail: szakal@biol.uw.edu.pl

F. Pensec $\cdot$ C. Bertsch

UFR Pluridisciplinaire Enseignement Professionnalisant Supérieur, Laboratoire Vigne Biotechnologie et Environnement EA 3391, Université de Haute-Alsace, 33, rue de Herrlisheim, 68000 Colmar, France
}

this review. The need for environmentally valuable and potentially profitable technologies for the recovery, recycling and upgrading of residues from fruit processing is also discussed.

Keywords Cuticular waxes $\cdot$ Fruit peel $\cdot$ Health benefits $\cdot$ Triterpenoids

\section{Introduction}

Through the ages, folk medicine has established the value of certain foods in human health maintenance. There is now mounting evidence that the healthiest diets are those loaded with plant foods. The health benefits ascribed to diets rich in fruit and vegetables include prevention, or at least reduction of the risk of chronic diseases occurring in the aging human population, such as cardiovascular disease, diabetes and cancer. In primary prevention, a diet rich in plantderived food is the preferred treatment option for early type-2 diabetes and hypercholesterolemia (Hooper and Cassidy 2006). Such a diet can also lower the blood pressure, reduce the risk of heart disease and stroke, prevent some gastrointestinal problems like diverticulosis, and lower the risk of Alzheimer's disease, cataracts and macular degeneration of the eye, as well as other age-related functional declines (Willet 1994; Liu 2003). There is considerable interest 
in bioactive compounds present in edible plants and thus in "letting your food be your medicine", as recommended by Hippocrates.

Bioactive plant constituents that are being actively studied for their health enhancing potential include flavonoids, phenolic acids, carotenoids, tocopherols, alkaloids, lignans, tannins, salicylates and glucosinolates, plus another important class of secondary metabolites, the triterpenoids. Formed by the cyclization of the linear squalene molecule, these tetra- or pentacyclic compounds are distinguished by their wide structural diversity (Hill and Connolly 2011, and their previous annual reviews). Moreover, they are found in plants not only in a free form, but also as esters and glycoside conjugates called saponins. All forms of triterpenoids are widely distributed in edible and medicinal plants, and consequently, they are an integral part of the human diet.

Triterpenoids have been shown to possess numerous biological activities and display various pharmacological effects such as antiinflammatory, antiulcer, antibacterial, antiviral (including anti-HIV), hepatoprotective, immunomodulatory, hypolipidemic and cholesterol-lowering, antiatherosclerotic, woundhealing, anticoagulant and anticarcinogenic properties, combined with relatively low toxicity (Akihisa et al. 2001; Patočka 2003; Liu 2005; Dzubak et al. 2006; Sun et al. 2006; Jäger et al. 2009; Kuo et al. 2009; Rezanka et al. 2009; Wolska et al. 2010; Bishayee et al. 2011; Thoppil and Bishayee 2011). The multifunctionality of triterpenoids makes them promising multi-targeting agents in the treatment of certain cancers and inflammatory diseases. Due to their ability to act at various stages in the process of carcinogenesis, namely to block NF- $\kappa \mathrm{B}$ activation, induce apoptosis and inhibit proliferation, invasion, metastasis and angiogenesis, these compounds may be considered for use in both chemoprevention and chemotherapy of cancer (Shishodia et al. 2003; Laszczyk 2009; Petronelli et al. 2009; Yadav et al. 2010).

Triterpenoids in their free and esterified forms are compounds with low polarity, and are therefore found in abundance in such plant parts as surface cuticle waxes and stem bark. Screens of various plant tissues to identify those that are rich in triterpenoids, point to fruit peels as a promising and highly available source material (Beindorff et al. 2001; Jäger et al. 2009).

\section{Fruit cuticle}

The surfaces of aerial parts (leaves, flowers, fruits and non-woody stems) of all terrestrial plants are covered with a hydrophobic layer called a cuticle (Müller and Riederer 2005). The cuticle forms a protective coating to prevent desiccation of the plant organs due to uncontrolled non-stomatal water loss, as well as the loss of organic and inorganic compounds by leaching. The cuticle is the first protective barrier against abiotic and biotic environmental stresses; it protects the plant surfaces against mechanical damage, abrasions, infiltration of xenobiotics and potentially harmful irradiance, like UV-B radiation, and it is the first line of defense against infection by plant pathogens. This interface between the plant and its environment is relevant for colonization by epiphytic microorganisms and host recognition by insects and pathogenic fungi (Bringe et al. 2006). In agriculture, it is the target site for sprays including fertilizers, growth regulators, fungicides, insecticides and herbicides.

The cuticle has two main components, a structural matrix called cutin, and wax. Cutin is a polyester-type biopolymer, composed mainly of hydroxy- and hydroxyepoxy-fatty acids. Waxes are embedded in the cutin and form a continuous layer on its top, so that intracuticular and epicuticular wax layers can be distinguished (Jetter et al. 2000). Waxes extracted from diverse plant species consist of homologous series of very-long-chain aliphatics, i.e. fatty acids, aldehydes, primary and secondary alcohols, ketones, alkanes and alkyl esters. Triterpenoids, tocopherols or aromatic compounds may also be present in trace amounts in some species, while dominating the mixture in others. It has been reported that triterpenoids are located almost exclusively in the intracuticular wax compartment (Jetter and Schäffer 2001; Buschhaus and Jetter 2011).

The chemical composition of cuticular waxes shows great variability, not only among different plant species, but also between different organs of an individual plant, and is affected by the stage of plant development, its geographic location and the local environmental conditions. The cuticular wax layer forms an interactive flexible interface between the plant and its environment. Thus, the chemical composition of these waxes influences the morphology, arrangement and microstructure of the plant surface, which determines the relative adhesion of water, 
pesticides, fungal spores, and other airborne deposits (Belding et al. 2000). This means that cuticular waxes are responsible for the wettability and permeability properties of the cuticle. On the other hand, the thickness and texture of the cuticular wax can be affected by environmental factors such as relative humidity, soil moisture, sunlight and temperature. Thus, external conditions can significantly influence the amount and composition of cuticular wax, which can have an impact on the vitality of leaves and the quality of the fruits. In the case of fleshy fruits, in particular, the cuticle is an important factor contributing to shelf life and post-harvest storability. Variation in the cuticle composition may underlie differences in fruit resistance to desiccation and microbial infection (Kosma et al. 2010). The composition of the cuticle has been associated with the incidence and severity of fungal disease, particularly the presence of biologically active compounds which can reduce germination of conidia or inhibit germ tube growth of various fungi (Belding et al. 2000).

Compared with plant vegetative organs, especially leaves, far less information is available regarding the triterpenoid content of fruit cuticular waxes. Data concerning the triterpenoids contained in fruit cuticular waxes and their possible impact on the health benefits associated with fruit consumption, and the usefulness of the fruit peel as a source of such compounds, are presented in this review. Although not strictly botanical terms, "peel" and sometimes "skin" are used to denote the outer fruit layers, composed of the cuticle and multiple cell types, including epidermis, collenchyma, and sometimes even parenchyma, depending on how the peels are removed. The term "flesh" refers to the pericarp material from which the peel has been removed; this tissue is predominantly composed of parenchyma and collenchyma (MintzOron et al. 2008).

\section{Apple}

Among all edible fruits, apples (Malus pumila Mill., Malus sylvestris L. (Mill.) var. domestica Borkh.) have one of the longest history of being significant part of the human diet and they also have proven medicinal properties (Cefarelli et al. 2006). The proverb "an apple a day keeps the doctor away" has been validated by numerous observations. Current annual global apple production is approximately 70 million tonnes (McGhie et al. 2012). The consumption of apples has been linked to the prevention of various chronic diseases and is believed to reduce the incidence of lung cancer, cardiovascular disease, symptoms of chronic obstructive pulmonary disease, and the risk of thrombotic stroke (He and Liu 2007). Apple peel exhibits more potent antioxidant and antiproliferative activity than apple flesh (Wolfe et al. 2003; Wolfe and Liu 2003), which suggests that the peel contains the majority of the bioactive phytochemicals.

\section{Triterpenoid composition of apple peel}

Epicuticular waxes of apples were studied as early as 1920, and ursolic acid was one of the first reported components (Belding et al. 1998; Verardo et al. 2003; Rudell et al. 2009). Apple peel has since been frequently recommended as a source of ursolic acid that may be utilized for various purposes (Beindorff et al. 2001; Glinsky and Branly 2001; Jäger et al. 2009). Several methods have been devised for the isolation of this compound from apple, including extraction of fresh homogenized peels with ethyl acetate (with a yield of $0.15 \%$ of fresh weight of peel obtained from the Red Delicious variety, $\mathrm{He}$ and Liu 2007), extraction of dried peel with chloroform $(0.7 \%$ of peel of the Fuji variety, Yamaguchi et al. 2008), and accelerated solvent extraction (ASE) of dried peel with ethyl acetate (with a yield ranging from 0.2 to $2.1 \%$ for 11 cultivars tested; Jäger et al. 2009). Besides various techniques of adsorption chromatography and HPLC, high speed counter-current chromatography (HSCCC) has also been used to purify this compound (Frighetto et al. 2008).

The occurrence of ursolic acid in apple peels is well documented, but there is a growing list of other triterpenoids that are also present in apple fruit cuticular wax and have yet to be fully investigated. Ma et al. (2005) reported the isolation of six triterpenoid compounds with ursane and oleanane skeletons (ursolic acid, $2 \alpha$-hydroxyursolic acid, euscaphic acid, $2 \alpha, 3 \alpha$-dihydroxy-urs-12-en-28-oic acid and $2 \alpha, 3 \alpha$ dihydroxy-olean-12-en-28-oic acid, uvaol) in an ethyl acetate extract of the peel of apples purchased from a supermarket in Beijing, China (Table 1). The occurrence of oleanolic acid (in addition to ursolic acid and uvaol) in the Holsteiner Cox variety was described by Ellgardt (2006), and $\beta$-sitosterol was found by 
Table 1 Triterpenoid profile of cuticular waxes of some edible fruits

\begin{tabular}{|c|c|c|c|c|c|c|}
\hline Fruit & Triterpenoid profile & Amount & $\begin{array}{l}\text { Predominant } \\
\text { compounds }\end{array}$ & $\begin{array}{l}\text { Method of wax } \\
\text { extraction }\end{array}$ & $\begin{array}{l}\text { Method of } \\
\text { triterpenoid } \\
\text { identification }\end{array}$ & Reference \\
\hline $\begin{array}{l}\text { Apple (Malus } \\
\text { pumila } \\
\text { Mill.) }\end{array}$ & $\begin{array}{l}\text { Euscaphic acid; } 2 \alpha, 3 \alpha \text { - } \\
\text { dihydroxy-olean-12- } \\
\text { en-28-oic acid; } \\
2 \alpha, 3 \alpha \text {-dihydroxy-urs- } \\
\text { 12-en-28-oic acid; } \\
2 \alpha \text {-hydroxyursolic } \\
\text { acid; ursolic acid, } \\
\text { uvaol }\end{array}$ & $\begin{array}{l}77 \% \text { of the } \\
\text { precipitate } \\
\text { obtained } \\
\text { from the } \\
\text { peel extract }\end{array}$ & $\begin{array}{l}\text { Ursolic acid (98\% of } \\
\text { triterpenoid mixture) }\end{array}$ & $\begin{array}{l}\text { Extraction } \\
\text { (supersonication) } \\
\text { of fresh peel with } \\
\text { ethyl acetate }\end{array}$ & NMR & $\begin{array}{l}\text { Ma et al. } \\
\text { (2005) }\end{array}$ \\
\hline $\begin{array}{l}\text { Apple (Malus } \\
\text { domestica } \\
\text { Borkh.) cv. } \\
\text { Holsteiner } \\
\text { Cox }\end{array}$ & $\begin{array}{l}\text { Oleanolic acid; ursolic } \\
\text { acid; uvaol }\end{array}$ & $\begin{array}{c}0.34-0.42 \% \\
\text { of peel d.w. }\end{array}$ & $\begin{array}{l}\text { Ursolic acid } \\
(0.28-0.34 \% \text { of peel } \\
\text { d.w. })\end{array}$ & $\begin{array}{l}\text { Extraction of } \\
\text { freeze-dried peel } \\
\text { with ethanol } \\
\text { (after preliminary } \\
\text { extraction with } \\
\text { n-hexane) }\end{array}$ & $\operatorname{HPLC}\left(\mathrm{R}_{\mathrm{T}}\right)$ & $\begin{array}{r}\text { Ellgardt } \\
(2006)\end{array}$ \\
\hline $\begin{array}{l}\text { Apple }(M . \\
\text { pumila } \\
\text { Mill. }) \text { cv. } \\
\text { Red } \\
\text { Delicious }\end{array}$ & 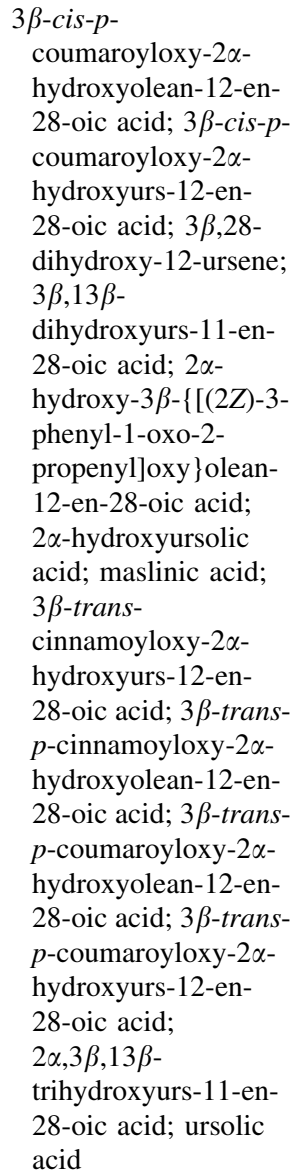 & $\begin{array}{l}0.15 \% \text { of the } \\
\text { mass of } \\
\text { fresh peels, } \\
19.5 \% \text { of } \\
\text { the peel } \\
\text { extract }\end{array}$ & $\begin{array}{l}\text { Ursolic acid }(0.15 \% \text { of } \\
\text { the mass of fresh } \\
\text { peels, } 18 \% \text { of the } \\
\text { peel extract) }\end{array}$ & $\begin{array}{l}\text { Extraction of } \\
\text { homogenized } \\
\text { fresh peel with } \\
\text { acetone and ethyl } \\
\text { acetate }\end{array}$ & NMR & $\begin{array}{l}\text { He and } \\
\text { Liu } \\
(2007)\end{array}$ \\
\hline
\end{tabular}


Table 1 continued

\begin{tabular}{|c|c|c|c|c|c|c|}
\hline Fruit & Triterpenoid profile & Amount & $\begin{array}{l}\text { Predominant } \\
\text { compounds }\end{array}$ & $\begin{array}{l}\text { Method of wax } \\
\text { extraction }\end{array}$ & $\begin{array}{l}\text { Method of } \\
\text { triterpenoid } \\
\text { identification }\end{array}$ & Reference \\
\hline $\begin{array}{l}\text { Grape berry } \\
\text { (Vitis } \\
\text { vinifera L.) } \\
\text { cv. } \\
\text { Cabernet } \\
\text { Sauvignon }\end{array}$ & $\begin{array}{l}\text { Oleanolic acid; } \\
\text { oleanolic aldehyde; } \\
\beta \text {-sitosterol; } \beta \text { - } \\
\text { sitosterol-3- } O \text { - } \beta \text {-D- } \\
\text { glucoside; } \beta \text { - } \\
\text { sitosterol-6'- } \\
\text { linolenoyl-3-O- } \beta \text {-D- } \\
\text { glucopyranoside }\end{array}$ & $\begin{array}{l}0.075 \% \text { of } \\
\text { fresh skin } \\
\text { mass }\end{array}$ & $\begin{array}{l}\text { Oleanolic acid ( } 86 \% \\
\text { of triterpenoid } \\
\text { mixture) }\end{array}$ & $\begin{array}{l}\text { Extraction of } \\
\text { blended skin with } \\
\text { methanol and } \\
\text { ethyl acetate }\end{array}$ & NMR & $\begin{array}{l}\text { Zhang } \\
\text { et al. } \\
\text { (2004) }\end{array}$ \\
\hline $\begin{array}{l}\text { Grape berry } \\
\text { (V. vinifera } \\
\text { L.) }\end{array}$ & $\begin{array}{l}\text { Oleanolic acid; } \beta \text { - } \\
\text { sitosterol; } \beta \text { - } \\
\text { sitosterol-3- } O-\beta \text {-D- } \\
\text { glucoside }\end{array}$ & $\begin{array}{l}0.027 \% \text { of } \\
\text { fresh berry } \\
\text { mass in cv. } \\
\text { Othello }\end{array}$ & $\begin{array}{l}\text { Oleanolic acid } \\
(0.003-0.016 \% \text { of } \\
\text { fresh berry mass })\end{array}$ & $\begin{array}{l}\text { Extraction of } \\
\text { detached and } \\
\text { homogenized } \\
\text { skin with ethyl } \\
\text { acetate }\end{array}$ & LC-MS & $\begin{array}{l}\text { Orbán } \\
\text { et al. } \\
(2009)\end{array}$ \\
\hline $\begin{array}{l}\text { Olive (Olea } \\
\text { europaea } \\
\text { L.) cv. } \\
\text { Coratina }\end{array}$ & $\begin{array}{l}\alpha \text {-amyrin; } \beta \text {-amyrin; } \\
\text { betulinic acid; } \\
\text { erythrodiol; maslinic } \\
\text { acid; oleanolic acid; } \\
\beta \text {-sitosterol, } \\
\text { stigmasterol, uvaol }\end{array}$ & $\begin{array}{l}52 \text { and } 26 \% \\
\text { of the total } \\
\text { wax extract } \\
\text { in green } \\
\text { and black } \\
\text { fruit, } \\
\text { respectively }\end{array}$ & $\begin{array}{l}\text { Oleanolic acid ( } 70 \text { and } \\
83 \% \text { of total } \\
\text { triterpenoids in green } \\
\text { and black fruit, } \\
\text { respectively) }\end{array}$ & $\begin{array}{l}\text { Immersion of } \\
\text { whole fruits in } \\
\text { chloroform }\end{array}$ & GC-MS & $\begin{array}{l}\text { Bianchi } \\
\text { et al. } \\
(1992)\end{array}$ \\
\hline $\begin{array}{l}\text { Olive }(O . \\
\text { europaea } \\
\text { L.) cv. } \\
\text { Arbequina }\end{array}$ & $\begin{array}{l}\text { Maslinic acid; } \\
\text { oleanolic acid }\end{array}$ & $\begin{array}{l}0.23 \text { and } \\
0.19 \% \text { of } \\
\text { fruit d.w. in } \\
\text { green and } \\
\text { black fruit, } \\
\text { respectively }\end{array}$ & $\begin{array}{l}\text { Maslinic acid }(0.18 \text { and } \\
0.15 \% \text { of fruit d.w. } \\
\text { in green mature and } \\
\text { black ripe fruit, } \\
\text { respectively) }\end{array}$ & $\begin{array}{l}\text { Extraction of } \\
\text { mechanically } \\
\text { obtained epicarp } \\
\text { with absolute } \\
\text { ethanol }\end{array}$ & $\mathrm{GC}\left(\mathrm{R}_{\mathrm{T}}\right)$ & $\begin{array}{l}\text { Guinda } \\
\text { et al. } \\
\text { (2010) }\end{array}$ \\
\hline $\begin{array}{l}\text { Tomato ( } L . \\
\text { esculentum } \\
\text { L.) }\end{array}$ & $\begin{array}{l}\alpha \text {-amyrin; } \beta \text {-amyrin; } \delta \text { - } \\
\text { amyrin; bauerenol; } \\
\text { cycloartenol; } \\
\text { germanicol; lupeol; } \\
\text { multiflorenol; } \beta \text { - } \\
\text { sitosterol; } \\
\text { stigmasterol; } \\
\text { taraxasterol; } \psi \text { - } \\
\text { taraxasterol; taraxerol }\end{array}$ & $\begin{array}{l}13.7 \% \text { of the } \\
\text { total wax } \\
\text { extract } \\
\text { (average } \\
\text { from } 26 \\
\text { cultivars) }\end{array}$ & $\begin{array}{l}\delta \text {-amyrin }(5.6 \% \text { of } \\
\text { wax extract, i.e. } \\
41.2 \% \text { of total } \\
\text { triterpenoids); } \beta \text { - } \\
\text { amyrin }(3.2 \% \text { of wax } \\
\text { extract }) ; \alpha \text {-amyrin } \\
(3 \% \text { of wax extract })\end{array}$ & $\begin{array}{l}\text { Dipping of whole } \\
\text { fruits into tert- } \\
\text { butylmethyl } \\
\text { ether/methanol } \\
(9: 1) \text { in ultrasonic } \\
\text { bath }\end{array}$ & GC-MS & $\begin{array}{l}\text { Bauer } \\
\text { et al. } \\
\text { (2004a, } \\
\text { b) }\end{array}$ \\
\hline $\begin{array}{l}\text { Tomato ( } L . \\
\text { esculentum } \\
\text { L.) cv. } \\
\text { MicroTom } \\
\text { (wild-type) }\end{array}$ & $\begin{array}{l}\alpha \text {-amyrin; } \beta \text {-amyrin; } \beta \text { - } \\
\text { amyrin derivative; } \delta \text { - } \\
\text { amyrin; cholesterol; } \\
\text { lanosterol; lupeol } \\
\text { derivative I; } \\
\text { multiflorenol; } \beta \text { - } \\
\text { sitosterol; } \\
\text { stigmasterol; } \\
\text { taraxasterol; } \psi \text { - } \\
\text { taraxasterol; taraxerol }\end{array}$ & $\begin{array}{l}21 \% \text { of the } \\
\text { total wax } \\
\text { extract (in } \\
\text { mature } \\
\text { fruit) }\end{array}$ & $\begin{array}{l}\alpha-, \beta-, \delta \text {-amyrins }(76- \\
91 \% \text { ot total } \\
\text { triterpenoids) }\end{array}$ & $\begin{array}{l}\text { Extraction of } \\
\text { enzymatically } \\
\text { isolated cuticle } \\
\text { with chloroform }\end{array}$ & $\mathrm{GC}-\mathrm{MS}$ & $\begin{array}{l}\text { Leide } \\
\text { et al. } \\
(2007)\end{array}$ \\
\hline
\end{tabular}

$G C-M S$ gas chromatography-mass spectrometry, $H P L C$ high performance liquid chromatography, $L C-M S$ liquid chromatographymass spectrometry, $N M R$ nuclear magnetic resonance, $R_{T}$ retention time

Verardo et al. (2003) in the cultivars Florina, Golden B and Ozark Gold. Thirteen triterpenoids were isolated and identified by He and Liu (2007) in the peel of Red Delicious apples (Table 1), with ursolic acid, $2 \alpha-$ hydroxyursolic acid, $3 \beta$-trans-cinnamoyloxy- $2 \alpha$-hydroxyurs-12-en-28-oic acid, 3 $\beta$-trans- $p$-coumaroyloxy-2 $\alpha$-hydroxyurs-12-en-28-oic acid (Fig. 1) and $3 \beta$-trans-p-cinnamoyloxy-2 $\alpha$-hydroxyolean-12-en- 

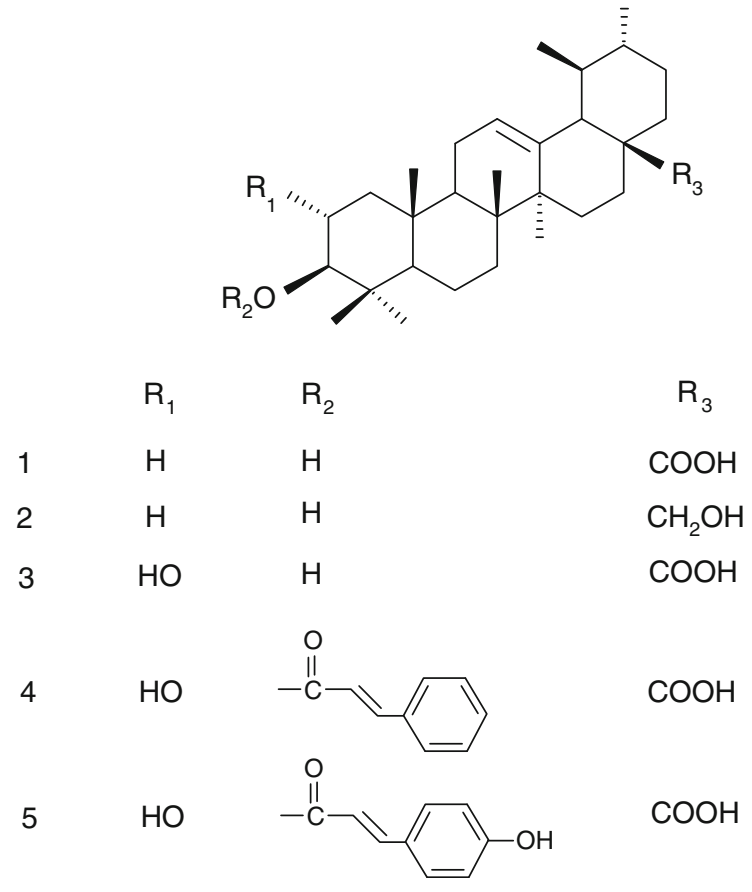

Fig. 1 Structures of some triterpenoids occurring in apple ( $M$. pumila) fruit cuticular waxes: ursolic acid (1), uvaol (2), $2 \alpha$ -

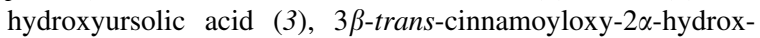
yurs-12-en-28-oic acid (4), 3 $\beta$-trans- $p$-coumaroyloxy- $2 \alpha$-hydroxyurs-12-en-28-oic acid (5)

28-oic acid being the most abundant compounds. Nine ursane (including annurcoic and annurconic acids, compounds described for the first time), two oleanane and two lupane triterpenes, along with two steroids were isolated and identified in whole apples of the Annurca cultivar (Cefarelli et al. 2006). A recent comprehensive analysis of triterpene acids in seven apple cultivars from New Zealand performed using UHPLC-HRMS, demonstrated the presence of multiple isomeric compounds of the ursane-type acids (oxo, hydroxyl, dihydroxy, trihydroxy, etc.) (McGhie et al. 2012).

Apples are a very good example of how the quantity and composition of epicuticular wax can vary between cultivars (Belding et al. 1998; Belding et al. 2000; Verardo et al. 2003). For example, among twelve cultivars tested, the triterpenoid content ranged from $32 \%$ of cuticular wax extract obtained from Royal Gala apples to almost $70 \%$ in Pure Gold fruit (Belding et al. 1998). The amounts of ursolic acid, oleanolic acid and uvaol were higher by 17, 15 and $29 \%$, respectively (Table 1), in cuticular wax of Holsteiner Cox apples originating from integrated production (restricting the use of pesticides and fertilizers to a required minimum) compared with those produced organically (production based on recycling and local renewable resources with a ban on the use of chemical pesticides and commercial fertilizers), which indicates that the method of cultivation can influence the apple peel composition (Ellgardt 2006). The triterpenoid content of apple peel can also be significantly affected by post-harvest conditions including cold storage of fruit, as was revealed by studies on metabolomic changes associated with oxidation during the development of superficial scald symptoms (Rudell et al. 2009). In turn, cuticular wax composition can influence the quality of fruits during storage and their shelf life. For example, Golden Delicious apples lose water more rapidly than other cultivars in storage, which is commonly thought to be due to the smaller wax mass (Belding et al. 1998). At the same time, the cuticular wax of these apples contains the highest proportion of triterpenoids (54-70\% of total wax extract), which might explain the poor water retention of this cultivar, since a high level of triterpenoids in cuticular wax is not positively correlated with water impermeability. The composition of the cuticular wax of apples has also been studied with regard to its possible relevance in the avoidance of fruit damage caused by insects and pathogens such as Peltaster fructicola and Leptodontidium elatius, although the relative proportions of triterpenoids were not found to be related to the severity of sooty blotch disease caused by these fungi (Belding et al. 2000).

Apple peels are a waste product of juice and canned fruit production, and their utilization to generate a value-added food ingredient can be economically beneficial (Wolfe and Liu 2003; Djilas et al. 2009). However, there have been no studies on the consequences of the commercial practice of waxing apples on the occurrence of triterpenoids in apple peel. Prior to packaging of apple fruits, they are washed by scrubbing the surface to remove field dust and chemical residues, which removes approximately $50 \%$ of the natural wax coating. To replace the original protective layer, supplementary waxes (usually carnauba or shellac, which do not contain ursolic acid) are applied to the surface of apples. However, as triterpenoids are most likely to be localized in the deeper layers of plant cuticular waxes, i.e. intracuticular wax substructure (Buschhaus and Jetter 2011), it is possible that this treatment does not remove all these 
compounds from the peel of packed and waxed apples sold in supermarkets.

Pharmacological properties of triterpenoids found in apple peel

A diet enriched in apples has been associated with the reduced incidence of many chronic diseases, including lung cancer (Wolfe and Liu 2003). The antitumor activity of triterpenoids isolated from apple peel has been investigated with a variety of tests. Ursolic acid and $2 \alpha$-hydroxyursolic acid exhibited in vitro growth inhibitory activity against four tumor cell lines, HL60, BGC, Bel-7402, and HeLa, with $\mathrm{ED}_{50}$ values ranging from 45 to $72 \mu \mathrm{g} / \mathrm{ml}$ (Ma et al. 2005). Moreover, ursolic acid can serve as a precursor of more potent cytotoxic derivatives, such as the 3 -amino and 28-aminoalkyl compounds, the former of which was shown to be 20-times more potent than the parent compound (Ma et al. 2005). Most of the triterpenoids, including their $p$-coumaryloxy-esters, isolated from apple peel of the Red Delicious variety by $\mathrm{He}$ and Liu (2007), showed potent antiproliferative activities against human cell lines of HepG2 liver cancer, MCF-7 breast cancer and Caco-2 colon cancer. Yamaguchi et al. (2008) reported a slight harmful effect of ursolic acid isolated from apple peel of the Fuji variety on normal mouse embryo cells (growth inhibition by $7 \%$ at an ursolic acid concentration of $10 \mu \mathrm{M}$ ), which contrast with its efficacy in suppressing the growth (by $82 \%$ ) of highly metastatic tumorigenic cells. However, higher concentrations of ursolic acid can also be harmful to healthy cells: a concentration of $20 \mu \mathrm{M}$ suppressed the growth of more than $90 \%$ of tumorigenic cells, but it also affected about $60 \%$ of normal cells.

Ursolic acid itself is ubiquitous in medicinal and edible plants (e.g. herbs such as basil, peppermint, rosemary), and it has attracted attention due to its diverse pharmacological properties including antitumorigenic effects exerted by inhibition of the STAT3 pathway. This compound was shown to inhibit NF- $\kappa \mathrm{B}$ activation induced by carcinogenic agents through suppression of $\mathrm{I} \kappa \mathrm{B} \alpha$ kinase and $\mathrm{p} 65$ phosphorylation, and it also suppressed TNF-induced expression of cyclin D1, cyclooxygenase 2 (COX-2) and matrix metalloproteinase 9 , which are involved in the initiation, promotion and metastasis of tumors (Shishodia et al. 2003).

\section{Grape berry}

Grapevine (Vitis vinifera L.), which is native to southern Europe and Western Asia, is cultivated also on other continents (in addition to North American grapevine species like V. labrusca, V. rotundifolia), and its fruit is highly valued for its great economic importance and many health benefits. In the context of the Mediterranean dietary tradition, grape consumption is linked to reduction of the incidence of chronic illnesses, such as cancer, cardiovascular diseases, ischemic stroke, neurodegenerative disorders and aging (Iriti and Faoro 2009; Yadav et al. 2009; Ali et al. 2010). Grapevine products (fresh berries, raisins, juice, wine) are well known for their antioxidant content, and therefore, grape extracts are also widely used in various cosmetic formulas. Many studies have shown that active components, including polyphenols, resveratrol, hydroxytyrosol and recently melatonin, may contribute to the health benefits associated with regular consumption of grape products (Leifert and Abeywardena 2008; Ali et al. 2010; Vislocky and Fernandez 2010; Fernández-Mar et al. 2011). However, relatively few studies have focused on the presence and health promoting properties of triterpenoids from grape berries.

Triterpenoid composition of grape berry skin

Some preliminary investigations of the composition of grape berry wax were carried out as early as 1892 , and by 1938 , oleanolic acid and $\beta$-sitosterol had been identified (Radler and Horn 1965). Oleanolic acid was the main constituent of chloroform extracts of cuticular waxes from the fruits of the sultana vine as well as those of several American Vitis species and hybrids (Radler 1965a, b; Radler and Horn 1965). The amount of oleanolic acid in wax extract of young and mature sultana vine fruits ranged from 45 to $65 \%$, respectively, and accounted for $50 \%$ of the total wax extract obtained from dried grapes (Radler and Horn 1965; Radler 1965a). The occurrence of remarkable amounts of oleanolic acid in grape berry wax was confirmed in many subsequent studies performed on various grape cultivars. This compound was reported to constitute $50-80 \%$ of the total weight of wax extracts obtained from fruits of several Japanese grape varieties at the harvest stage (Yamamura and Naito 1983), and it was the main component of grape berry cuticular waxes of 
Fig. 2 Structures of some triterpenoids occurring in grape berry ( $V$. vinifera) fruit cuticular waxes: oleanolic acid (1), oleanolic aldehyde (2), erythrodiol (3), $\beta$-sitosterol (4), $\beta$ sitosterol-3-O- $\beta$-Dglucoside (5), $\beta$-sitosterol$6^{\prime}$-linolenoyl-3-O- $\beta$-Dglucopyranoside $(6)$

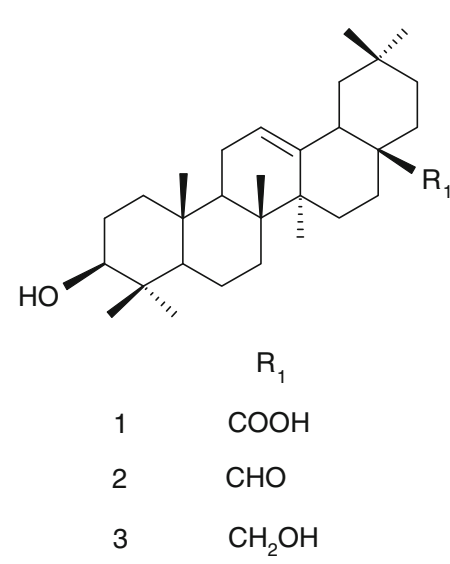

4

$\mathrm{R}_{2}$

$\mathrm{H}$

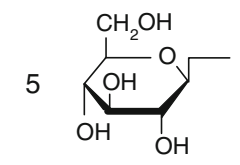

6

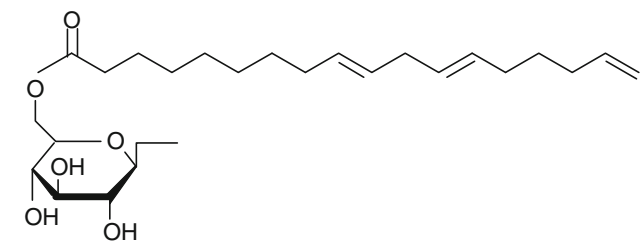

three clones of Pinot noir (from Champagne vineyards) at all stages of fruit development (Comménil et al. 1997). Furthermore, a comparison of twelve grape varieties (five white and seven red varieties originating from the Hungarian Eger and Alföld wine regions) revealed significant variation in the oleanolic acid content, ranging from 31 to $162 \mathrm{mg} / \mathrm{kg}$ of fresh berry mass calculated for fruit wax, or from 157 to $239 \mathrm{mg} / \mathrm{kg}$ of fresh berry mass when calculated for whole fruit skins (Orbán et al. 2009).

Besides oleanolic acid, other triterpenoids have been identified in grape berry cuticular wax, namely oleanolic aldehyde (Dagna et al. 1982; Zhang et al. 2004), erythrodiol (Dagna et al. 1982) (Fig. 2) and a group of phytosterols and their derivatives (Dagna et al. 1982; Le Fur et al. 1994; Zhang et al. 2004; Orbán et al. 2009). The phytosterols $\beta$-sitosterol, campesterol and stigmasterol were detected in chloroform extracts of the dried skin of berries obtained from fourteen grape varieties of the Piedmont region (Dagna et al. 1982). Subsequently, lanosterol was identified in Folch mixture (chloroform:methanol 2:1, $\mathrm{v} / \mathrm{v}$ ) extracts from lyophilised skins of Chardonnay grape berries from Burgundy (Le Fur et al. 1994). The level of phytosterols exhibited a characteristic pattern of fluctuation: increasing at peak maturity and decreasing during the last stage of ripening. The predominant steroid compound in the grape berry cuticular wax was $\beta$-sitosterol, accounting for $0.1 \%$ of dry berry skin and representing 86-89\% of the total detected phytosterols. The levels of stigmasterol and campesterol were estimated at 85 and $43 \mu \mathrm{g} / \mathrm{g}$ of dry weight, respectively, while lanosterol was found in much lower amounts (Le Fur et al. 1994). $\beta$-Sitosterol and its monoglycosidic derivative, $\beta$-sitosterol-3- $O-\beta$ D-glucoside (Fig. 2) were identified by liquid chromatography-mass spectrometry (LC-APCI-MS) in ethyl acetate extracts of berry skins of grapes from the Eger and Alföld regions (Table 1), with amounts ranging among varieties from 12 to $73 \mathrm{mg} / \mathrm{kg}$ of fresh berry mass for $\beta$-sitosterol, and $2-13 \mathrm{mg} / \mathrm{kg}$ of fresh berry mass for its monoglucoside (Orbán et al. 2009). In addition to $\beta$-sitosterol-3- $O$ - $\beta$-D-glucoside, another steroid derivative, $\beta$-sitosterol- $6^{\prime}$-linolenoyl3-O- $\beta$-D-glucopyranoside (Fig. 2) was found in methanol extracts of blended skins of Cabernet Sauvignon grape berries harvested from Michigan State University Horticulture farm (Table 1, Zhang et al. 2004). Studies examining Thompson seedless raisins (Rivero-Cruz et al. 2008) and grape pomace from the red Sicilian cultivar Nerello Mascalese (Amico et al. 2004), identified the compounds betulin, betulinic 
acid, lupeol, oleanolic acid acetate and $\beta$-sitosterol glucoside peracetate, which expanded the list of triterpenoids found in grape berry cuticular waxes.

Participation of triterpenoids in the spatial arrangement of grape berry wax

The grape berry cuticle is characterized by a high content of waxes (about $25 \%$ of cuticular weight) and a high degree of molecular order (Casado and Heredia 1999, 2001). Oleanolic acid, although highly abundant in this layer (up to $60 \%$, or even more, of the total wax) appears not to contribute to the ordered crystalline structure of the cuticle. A molecular model of the spatial arrangement of oleanolic acid and the main aliphatic compound, n-hexacosanol, has been proposed to explain the organization of the grape berry cuticle. Oleanolic acid can form a dimer via hydrogen bond interactions between the hydroxyl group of one molecule and the carboxyl group of a second molecule. The remaining functional groups may interact with complementary groups of other molecules, including aliphatic alcohols, forming a tri-dimentional arrangement (Casado and Heredia 1999). The ultrastructure and chemical composition of grape cuticular waxes may also play an important role in the resistance of grape berries to Botrytis cinerea, although a direct relationship between the triterpenoid content and susceptibility to bunch rot disease caused by this pathogen has yet to be confirmed (Comménil et al. 1997).

Pharmacological properties of triterpenoids found in grape berry skin

The high abundance of oleanolic acid in grape berry cuticular wax can contribute to health benefits ascribed to grape consumption. Like its isomer ursolic acid, oleanolic acid is known to have numerous pharmacological properties including anticancer, antiinflammatory, antidiabetogenic, antimicrobial, hepato- and cardioprotective, anti-HIV and anti-multiple sclerosis effects (Liu 2005; Yeung and Che 2009, Martín et al. 2010). Oleanolic acid isolated from Cabernet Sauvignon grape skin was shown to be capable of in vitro regulation of insulin secretion, significantly stimulating insulin production at concentrations ranging from 6 to $50 \mu \mathrm{g} / \mathrm{ml}$, in a dosedependent manner, similarly to glucose. Oleanolic aldehyde was also able to influence insulin secretion in vitro. Furthermore, oleanolic acid applied to cells at a concentration of $100 \mu \mathrm{g} / \mathrm{ml}$ inhibited COX-2 enzyme activity by $10 \%$. These findings suggest that the consumption of whole grape berries may help to reduce the incidence of type- 2 diabetes and inflammation (Zhang et al. 2004). In China, V. vinifera berries called suosuo grapes, produced in the Turpan, Shanshan and Hetian regions of Xinjiang, have been used in Uighur folk medicine for the prevention and treatment of liver disorders. In traditional medicine, these grapes have also been used to treat diarrhea, hepatitis and stomach aches. The grape berry triterpenoid fraction, containing mainly oleanolic acid, exhibited protective effects against immunological liver damage in vitro (Liu et al. 2007). This hepatoprotective activity was later confirmed by in vivo experiments in mice (Liu et al. 2010). Oleanolic acid and oleanolic aldehyde obtained from Thompson seedless raisins displayed significant antimicrobial activity (MIC values of $250-625 \mu \mathrm{g} / \mathrm{ml}$ ) against Streptococcus mutans and Porphyromonas gingivalis, two oral pathogens most commonly associated with human dental carries and periodontal diseases (Rivero-Cruz et al. 2008). The growth of these pathogens was also inhibited by other triterpenoid compounds occurring in raisins, such as betulin, betulinic acid, $\beta$ sitosterol and $\beta$-sitosterol glucoside. The potential benefits to oral health and disease prevention due to the presence of antimicrobial triterpenoids, means that raisins may represent a healthy alternative to widely consumed sugary snack foods (Wu 2009). Moreover, $\beta$-sitosterol and its glucoside possess a variety of beneficial properties and were shown to have serum cholesterol lowering, cancer preventative, antimutagenic and anti-inflammatory activities (Awad and Fink 2000; Piironen et al. 2000; Villasenor et al. 2002). Lupeol, another triterpene compound isolated from grape pomace (Amico et al. 2004), is also known for its significant pharmacological properties, including anticancer, antiprotozoal, chemopreventive and anti-inflammatory activities (Gallo and Sarachine 2009).

Numerous health benefits, including protection against heart disease, are ascribed to the moderate consumption of wine, one of the most popular grape berry products. A worldwide monitoring system for cardiovascular diseases organized by the World Health Organization showed that the mortality rate 
from coronary disease is much lower in France than in other industrialized countries despite similar consumption of saturated fats (World Health Statistics Annual 1989). This phenomenon, called the French paradox, has mostly been explained by the high wine intake in France, and is usually linked to the cardioprotective properties of phenolics (Frankel et al. 1993). There have been few studies examining triterpenoid compounds occurring in wine. The triterpene composition of five red wines, i.e. Bordeaux Graves 2000, Bordeaux Haut médoc 1998, Bordeaux Pessac Léognan 1999, Burgundy 1996 and 2000, and two white wines, i.e. Bordeaux Graves 1999 and 2000, was compared and a considerable qualitative variation was observed. $2 \alpha, 3 \beta, 19 \alpha$-Trihydroxyolean-12-ene24,28 -dioic acid and $2 \alpha, 3 \beta, 19 \alpha, 23$-tetrahydroxyolean-12-ene-24,28-dioic acid were found in every wine tested except Burgundy 1996. 28- $\beta$-D-Glucopyranosyl-trihydroxyolean-12-ene-24,28-dioic acid was identified in Bordeaux Haut Médoc 1998, Bordeaux Pessac Léognan 1999 and Bordeaux Graves 2000 , while $28-\beta$-D-glucopyranosyl-tetrahydroxyolean-12-ene-24,28-dioic acid was found only in Burgundy 1996 and Bordeaux Graves 2000. Although the identification of triterpenoids occurring in wine is very interesting, this study also underlined the fact that some of these compounds could come from the oak wood barrels used during wine maturation (Aramon et al. 2003). This was recently confirmed by the detection in wine of two novel compounds, quercotriterpenoside I and II: oleanane-type triterpenes substituted with galloyl and glucosyl residues that originate from oak barrels (Marchal et al. 2011). Grape pomace, which is estimated to represent $13 \%$ of the grape by weight, is a significant by-product of the process of wine-making and a promising source of useful compounds: not only polyphenols, but also biologically active triterpenoids. For example, a freeze-dried grape pomace macerate of red grape Nerello Mascalese was defatted with n-hexane and extracted with ethyl acetate to obtain oleanolic acid, lupeol and $\beta$-sitosterol 3 - $O$-glucoside with yields of $0.1575 \%, 0.0085 \%$ and $0.0249 \%$ of pomace dry weight, respectively (Amico et al. 2004).

\section{Olive}

Olive (Olea europaea L.) is a fruit of major agricultural importance in the Mediterranean region. Olive tree cultivation started 6,000 years ago and thus the olive is the oldest cultivated tree. Olive oil, one of the basic components of the traditional Mediterranean diet, has become increasingly popular due to its beneficial nutritional and medicinal properties, including reduction of the risk of coronary heart disease and atherosclerosis, the prevention of several types of cancer and modification of the immune and inflammatory responses (Owen et al. 2004; Ortega 2006). However, while the beneficial effects of the monounsaturated fatty acids and phenols in olive oil are well recognized, much less attention has been paid to other compounds, including triterpenoids (Stiti and Hartmann 2012).

Triterpenoid composition of the olive skin

The presence of the pentacyclic triterpene acids, maslinic (Fig. 3) and oleanolic, in olive fruits has long been known (Vioque and Maza 1963; Bianchi et al. 1992; Pérez-Camino and Cert 1999). These compounds were identified as the major components of the chloroform-soluble waxes of olive fruits of the Italian cultivar Coratina collected in Pescara, accounting for 26 and $38 \%$ of the total wax of green mature and black ripe olives, respectively. This study also

Fig. 3 Structures of some triterpenoids occurring in olive (O. europaea) fruit cuticular waxes: I maslinic acid, II betulinic acid

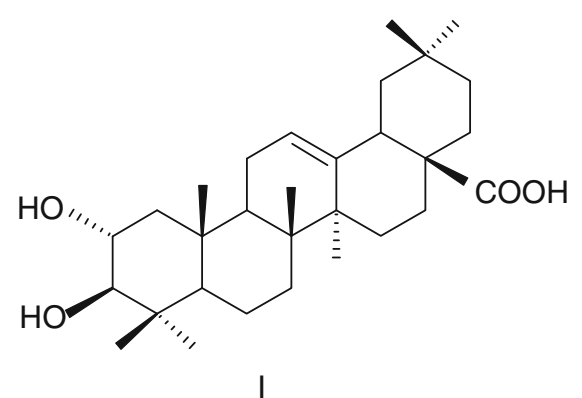

I

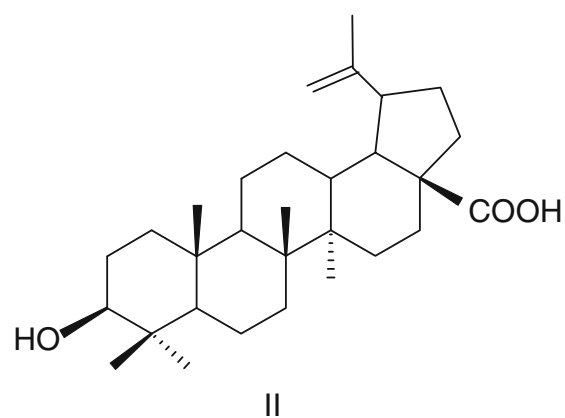


revealed differences between green and black olives in the content of the dihydroxy alcohols, erythrodiol and uvaol, which were present in substantial amounts $(14 \%)$ in the wax of green olives, but only in traces in that of black olives. In addition, small amounts of betulinic (Fig. 3) and ursolic acids, $\alpha$ - and $\beta$-amyrins, as well as phytosterols, mainly $\beta$-sitosterol and stigmasterol, were detected (Table 1) (Bianchi et al. 1992). Significant amounts of triterpene acids in olive cuticular waxes (maslinic and oleanolic acid representing 55-68\% and 31-44\% of total wax extract, respectively) were also reported for cutivars Cipressino, Dritta and Leccino (Bianchi et al. 1994). The formation of triterpenoids throughout fruit ontogeny at 13 distinct stages of development over a period of 33 weeks after flowering was studied in the olive cultivar Chemlali by Stiti et al. (2007). Numerous tetra- and pentacyclic triterpenes and sterols were identified in a dichloromethane/methanol (2:1) extract of entire olive fruit, including compounds of different carbon skeletons: oleanane, ursane, lupane, taraxane, euphane, baccharane and lanostane. At the onset of fruit development, between 12 and 18 weeks after flowering, high amounts of the triterpene monols $(\alpha-$ and $\beta$-amyrins as well as 28 -nor- $\alpha$ - and 28 -nor $\beta$ amyrins; $0.043 \%$ of fruit dry weight, $13 \%$ of all triterpenoids) as well as more oxygenated compounds, such as triterpene diols (mainly erythrodiol and uvaol; $0.07 \%$ of d.w., $21 \%$ of triterpenoids) and acids (3epi-betulinic, oleanolic, maslinic and ursolic; $0.21 \%$ of d.w., $66 \%$ of triterpenoids), were detected. From 21 weeks after flowering, when the olive fruit reached its final size and began to turn from green to purple, $\alpha$ and $\beta$-amyrins were no longer present, whereas the class of methylsterols started to be formed. The level of diols decreased to $0.002 \%$ of d.w. $(0.5 \%$ of triterpenoids), while the content of triterpene acids reached a peak of almost $0.4 \%$ of d.w. (99\% of total triterpenoids). In the last stage of fruit development, sterol end products were progressively accumulated in larger amounts, while the level of triterpene acids decreased to $0.25 \%$ of d.w. During the earlier phases of fruit growth, oleanolic acid was the predominant triterpenoid, followed by maslinic acid; whereas in ripe olives, maslinic acid was the most abundant. In the 12th week after flowering, oleanolic acid accounted for $40 \%$ of total triterpenoids and maslinic acid represented $26 \%$. Subsequently this ratio changed, and by the 30th week after flowering, the level of oleanolic acid had decreased to $38 \%$, while maslinic acid had increased to $61 \%$ of total triterpenoids. Thus, the profile and the content of different triterpenoids in olive fruit seemed to be significantly influenced by the fruit developmental stage. This finding was confirmed for the three main Spanish olive cultivars, Picual, Hojiblanca and Arbequina, harvested in La Rinconada (Seville). The total triterpene content was higher in the unripe fruits (0.21-0.23\% of fruit d.w., depending on the cultivar) and diminished as ripening proceeded, with a decrease of $20 \%$ between the green mature and the black ripe stages (final content $0.17-0.19 \%$ of d.w). The ratio of maslinic and oleanolic acids was also dependent on the olive cultivar, with levels of the former 2.5-fold higher than those of the latter in fruits of the Pictual and Hojiblanca cultivars, and four fold higher in Arbequina. A study of the distribution of pentacyclic triterpenoids among Arbequina olive fruit tissues revealed that maslinic and oleanolic acids were exclusively found in the epicarp, which pointed to the cuticular waxes as the main location of these compounds in the olive fruit (Table 1, Guinda et al. 2010).

The level of triterpenoids in olives that are sold in the market can be significantly influenced not only by the cultivar or the stage of fruit ripeness, but also by the method of processing. Higher concentrations of maslinic and oleanolic acids were found in olives that had not been treated with alkali (turning colour olives, natural black olives), whereas pitting and stuffing did not significantly affect the level of these compounds. Treatment with $\mathrm{NaOH}$, which is employed to debitter the fruits, was shown to cause the loss of triterpene acids due to their solubilization (after sodium salt formation) in alkaline solutions (Romero et al. 2010).

\section{Pharmacological properties of triterpenoids found in the olive skin}

Olive triterpenoids have been attributed numerous health-promoting properties, such as anticancer (Martín et al. 2009; Juan and Planas 2010), antihyperglycemic (Liu et al. 2011) and antiparasitic activities (De Pablos et al. 2010; Moneriz et al. 2011). An extract from the skin of olive fruits, composed mainly of maslinic $(73 \%)$ and oleanolic $(26 \%)$ acids, inhibited proliferation and induced apoptosis in HT-29 human colon cancer cells in vitro (Juan et al. 2006). Subsequent studies on the activities of individual compounds revealed that oleanolic acid had a 
moderate antiproliferative effect on HT-29 cells $\left(\mathrm{EC}_{50}\right.$ of $160 \mu \mathrm{mol} / \mathrm{l})$ and simultaneous moderate cytotoxicity at concentrations higher than $250 \mu \mathrm{mol} / \mathrm{l}$, whereas maslinic acid inhibited cancer cell growth with an $\mathrm{EC}_{50}$ of $101 \mu \mathrm{mol} / \mathrm{l}$ without necrotic effects. Oleanolic acid failed to activate caspase-3, a prime apoptosis protease, whereas maslinic acid increased the activity of this enzyme by $3,3.5$ and five fold at non-toxic concentrations of 10,25 and $50 \mu \mathrm{mol} / \mathrm{l}$, respectively. Thus, maslinic acid was proposed as a promising new compound for the chemoprevention of colon cancers (Juan et al. 2008). An in vivo study on hyperlipidemia induced in rats by a high cholesterol diet, revealed that posterior supplementation with olive pomace extracts rich in maslinic and oleanolic acids significantly modulated the consequent high levels of serum cholesterol and triglycerides, suggesting the possibility of utilizing olive pomaces for the prevention and treatment of hyperlipidemia (Liu et al. 2011). The triterpenoids occurring in olive pomace oil, maslinic and oleanolic acids as well as erythrodiol and uvaol, induced vasorelaxation in the aorta of hypertensive rats (Rodriguez-Rodriguez et al. 2006). Erythrodiol and uvaol were also found to be potent inhibitors of the proliferation of human $1321 \mathrm{~N} 1$ astrocytoma cells in vitro, suggesting that these triterpenoids, which are capable of crossing the blood-brain barrier, may have the potential for use in prevention and treatment of brain cancers. It has been suggested that the induction of apoptosis by these compounds is mediated by the activation of a ROS/JNK (reactive oxygen species/cJun N-terminal kinase) pathway (Martín et al. 2009).

Several studies have indicated that maslinic acid is a potent antiparasitic agent. When applied to erythrocytic cultures, maslinic acid hindered the maturation of Plasmodium falciparum (the pathogen causing malaria) from the ring to the schizont stage, and could thus prevent the release of merozoites and the subsequent invasion. Maslinic acid effectively inhibited the proteolytic processing of the merozoite surface protein complex as well as plasmodial metalloproteases of the M16 family. Moreover, several others putative targets of maslinic acid have been suggested, such as phospholipase A2. The identification of maslinic acid as a potential multi-target drug against the intra-erythrocytic cycle of Plasmodium may be highly significant for the treatment of malaria, because most antimalarials target only a single process of the parasite infective cycle, which favours the appearance of resistant mutants (Moneriz et al. 2011). Maslinic acid was also proposed as a new natural coccidiostatic therapy against Eimeria tenella, a parasite causing coccidiosis in chickens (Gallus domesticus), which has a considerable economic impact on poultry production. The anticoccidial index (ACI), expressing the release of oocysts estimated at 10 days post-infection, was higher in chickens given maslinic acid (210) than in those receiving sodium salinomycin (173), the conventional coccidiostatic treatment. Furthermore, maslinic acid was also observed to affect the gliding of Toxoplasma gondii (De Pablos et al. 2010).

Due to the localization of olive triterpenoids in fruit cuticular waxes, olive oil, the most popular olive fruit product, contains only small amounts of these compounds (Pérez-Camino and Cert 1999; Stiti and Hartmann 2012). The concentration of maslinic and oleanolic acids depends on the olive cultivar and the oil quality: extra virgin oils contain $<200 \mathrm{mg} / \mathrm{kg}$ of these triterpenoids, their content exceeds $300 \mathrm{mg} / \mathrm{kg}$ in virgin oil, and crude pomace oils have up to $10 \mathrm{~g} / \mathrm{kg}$ of these compounds, although the latter oils have to be refined before consumption (Pérez-Camino and Cert 1999; Romero et al. 2010). "Orujo" or "alpeorujo" olive oil, as it is called in Spain, obtained from the pomace remaining after the mechanical extraction of virgin oil and subsequent centrifugation of the olive paste, represents a rich source of biologically active triterpenoids (Rodriguez-Rodriguez et al. 2006; García et al. 2008). The olive oil industry generates large amounts of various wastes, which contain many important biologically active compounds, and there is growing interest in their recovery (Niaounakis and Halvadakis 2006; Fernández-Bolaños et al. 2006). For example, maslinic acid obtained from the solid waste from olive-oil production was successfully applied as a feed additive to stimulate growth and hepatic protein-turnover rates in rainbow trout (Onchorhynchus mykiss) (Fernández-Navarro et al. 2006).

\section{Tomato}

Tomato (Solanum lycopersicum L. or Lycopersicon esculentum L.) has achieved tremendous popularity over the last century and is now one of the most important fruit crops. It is cultivated in practically every country in the world-in outdoor fields, glasshouses and nethouses. 
Fig. 4 Structures of some triterpenoids occurring in tomato (L. esculentum) fruit cuticular waxes: I $\alpha$-amyrin, II $\beta$-amyrin, III, $\delta$-myrin, IV, lupeol, V, taraksasterol, VI, $\psi$-taraksasterol<smiles>C[C@H]1CC[C@]2(C)CC[C@]3(C)C(=CCC4[C@@]5(C)CC[C@@H](O)C(C)(C)C5CC[C@]43C)C2[C@@H]1C</smiles><smiles>C=C(C)C1CC[C@]2(C)CC[C@]3(C)C(CCC4[C@@]5(C)CC[C@H](O)C(C)(C)C5CC[C@]43C)C12</smiles>

III<smiles>C=C1CC[C@]2(C)CC[C@]3(C)C(CCC4[C@@]5(C)CC[C@H](O)C(C)(C)C5CC[C@]43C)C2[C@@H]1C</smiles><smiles>CC1=CC[C@]2(C)CC[C@]3(C)C(CCC4[C@@]5(C)CC[C@H](O)C(C)(C)C5CC[C@]43C)C2[C@@H]1C</smiles>

Triterpenoid composition of the tomato skin

In contrast to many other fruits, triterpenoid content of tomato cuticular waxes has been studied in great detail. The occurrence of $\alpha$-, $\beta$ - and $\delta$-amyrin (Fig. 4), taraxerol, taraxasterol, $\psi$-taraxasterol, lupeol, multiflorenol, germanicol, bauerenol, cycloartenol, stigmasterol and $\beta$-sitosterol (Table 1) was reported in cuticular wax extracted from the surface of tomato fruits (Bauer et al. 2004a). It is noteworthy that the chemical composition of the triterpenoid fraction of tomato fruit cuticular waxes is strikingly different from the previously described cuticular waxes of apple, grape berries and olive, where triterpene acids (maslinic, oleanolic and ursolic) are the most abundant compounds. These acids do not occur in tomato, where $\alpha$-, $\beta$ - and $\delta$-amyrins are the predominant compounds, with quantities that vary considerably in different cultivars and during the subsequent stages of fruit development (Bauer et al. 2004b).

Studies on the biosynthesis and function of triterpenoids in tomato fruit wax

Diverse cultivars and mutants of tomato have been collected over several decades, and almost one thousand monogenic stocks have been described so far, including mutants of the famous MicroTom, a miniature tomato with a rapid life cycle that is used as a model cultivar for functional genomics (Emmanuel and Levy 2002). Thus, strong genetic and genomic tools are available to investigate processes associated with tomato fruit development and ripening, including the biosynthesis of cuticle lipids and subsequent composition diversity during fruit ontogeny (MintzOron et al. 2008; Kosma et al. 2010; Wang et al. 2011), 
as well as the correlation between the chemical composition of the cuticular waxes and their function as a transpiration barrier (Vogg et al. 2004; Leide et al. 2007; Leide et al. 2011). In contrast to the vegetative organs, very little molecular information is available regarding the biosynthetic pathways that are active in the surfaces of reproductive organs such as fleshy fruits. Comparative transcriptome and metabolome analyses carried out on peel and flesh tissues during tomato fruit development revealed that different tissues play diverse roles in fruit ripening. Triterpenoids appear to be formed during early fruit expansion rather than full ripening, since the levels of the most abundant triterpenols ( $\alpha-, \beta$ - and $\delta$-amyrins) increased most significantly 25-42 days after flower anthesis (Mintz-Oron et al. 2008). Triterpenoid levels were found to nearly triple from the small green to the mature green stages of tomato fruit development, but changed only slightly during the transformation to the red ripe stage (Kosma et al. 2010). Two genes involved in biosynthesis of triterpenoids have been isolated from tomato fruits and functionally characterized by heterologous expression in yeast as well as overexpression in tomato. One encodes a $\beta$-amyrin synthase, which produced $\beta$-amyrin as a single product, while the other encodes a multifunctional oxidosqualene cyclase, which yielded a triterpenol mixture containing $\delta$-amyrin $(48 \%), \quad \beta$-amyrin (13\%), $\alpha$-amyrin (18\%), multiflorenol $(7 \%), \psi$ taraxasterol $(3 \%)$, taraxasterol $(6 \%)$ and two unindentified triterpenoids $(5 \%)$. The product profile of these two enzymes resembles the range and relative amounts of triterpenoids found in the fruit cuticle. Both enzymes were found to be expressed exclusively in the epidermis of the tomato fruit, indicating that their major function is to form the cuticular triterpenoids. However, the ratios of the specific transcripts did not fully explain the variation in the fruit triterpenoid profiles of different tomato cultivars, with a $\delta$-amyrin: $\beta$-amyrin: $\alpha$-amyrin ratios of $3: 3: 2$ in MicroTom and 3:2:2 in most other cultivars (Wang et al. 2011). Some mutants have a triterpenoid profile that is slightly different from wild-type plants. For example $\alpha$-, $\beta$ - and $\delta$-amyrin, $\beta$-amyrin derivative, lupeol derivative I, multiflorenol, taraxasterol, $\psi$ taraxasterol, lanosterol and stigmasterol were identified as common constituents of the fruit waxes of wildtype MicroTom and its lecer6 mutant (defective in a $\beta$ ketoacyl-coenzyme A synthase), whereas $\beta$-sitosterol and taraxerol were detected exclusively in the wildtype fruit (Table 1), and the occurrence of lupeol and lupeol derivative II was restricted to the cuticular wax of lecer6 fruits (Leide et al. 2007).

The lecer6 mutant was used to study the consequences of a deficiency in very-long-chain aliphatics synthesis for fruit wax composition and the properties of the cuticle as a transpiration barrier. The total amount of wax was only slightly reduced in the mutant plants, but n-alkanes with chain lengths beyond C30 were missing. The decrease in aliphatic components was compensated by a three to six fold increase in the level of triterpenoids, mainly $\alpha-\beta$ - and $\delta$-amyrins, accumulated in the intracuticular layer. Experimental removal of the epicuticular wax layer, accounting for one-third of the total wax cover on wild-type fruits, had only a moderate effect on transpiration, whereas the reduction of intracuticular aliphatics in the mutant caused a four fold increase in cuticle permeability. It was concluded that the major portion of the transpiration barrier is located in the intracuticular wax layer and is largely determined by its aliphatic constituents, since an increase in the level of cuticular triterpenoids could not compensate for the loss of aliphatics. Moreover, the composition of the wax mixture also influences the morphological structure of cuticular waxes, which is an important determinant of cuticle permeability. The wax barrier consists of impermeable clusters of crystalline zones embedded in a matrix of amorphous material, and the diffusion of water occurs mainly in the amorphous volume fractions. It was postulated that triterpenoids are localized exclusively in the amorphous zones, so the increase in their content caused spatial rearrangements, and this was the direct reason for the increase in cuticular transpiration (Vogg et al. 2004). The level of triterpenoids was found to differ significantly in wild-type MicroTom and its lecer6 mutant during the course of fruit maturation. The content of these compounds was initially similar in immature green fruits of both plants $(<20 \%$ of total wax), but at the stage of mature green fruit, the level of triterpenoids increased sharply to $80 \%$ of total wax in lecer6 and it remained at such a high level during all stages of fruit development until the red ripe and red overripe phases. In the wild-type plant, the triterpenoid content peaked in the mature green phase at $53 \%$ of total wax, and then displayed a continuous decline to $21 \%$ in red overripe fruit. With the exception of immature green fruits, the lecer6 
mutant exhibited three to eight fold increased water loss compared with the wild-type, thus confirming a direct relationship between the properties of the cuticular transpiration barrier and chemical modifications in cuticular wax composition (Leide et al. 2007). These findings were later confirmed in a comparison of wild-type tomato culivars John Baer and Pearson with their respective positional sterile ( $p s)$ mutants, which besides functional male sterility also showed striking phenotypic similarity to the MicroTom lecer6 mutant. The content of pentacyclic triterpenes and sterol derivatives in wild-type and $p s$ mutant fruit cuticular waxes was 19 and $44 \%$, respectively, with the most prominent triterpenoids being $\alpha-\beta$ - and $\delta$ amyrins in wild-types, and $\beta$-amyrin and cholesterol in ps mutants. The $p s$ mutant fruit showed a five to eight fold increase in water permeability compared with the corresponding wild-type tomatoes (Leide et al. 2011).

Recently, wild relatives of cultivated tomato have been studied to evaluate the relationship between evolution, structure and function of the cuticle. These species, Solanum Sect. Lycopersicon, evolved from a common ancestor about 7 million years ago and today they are endemic to an array of environments in the northern Andes and Galapagos Islands. They can still be crossed with $S$. lycopersicum and share a high degree of genomic synteny. However, striking differences in cuticular architecture and the quantities of cutin and waxes have been observed, with the wax coverage of the wild varieties exceeding that of cultivated tomatoes by up to seven fold. Triterpenoids were found to be the major non-aliphatic compounds of the fruit cuticles, accounting for $1-35 \%$ of the total wax, although they could not be detected in one species, $S$. pennellii. The predominant isomers were $\alpha$ , $\beta$ - and $\delta$-amyrins, with $\psi$-taraxasterol and taraxasterol present at much lower levels. However, in $S$. habrochaites, $\beta$-amyrin was the only pentacyclic triterpenoid detected. A correlation between a decreasing prevalence of triterpenoids and phylogenic distance from S. lycopersicum was identified. In addition, it was confirmed that besides evolutionary adaptation, environmental growth conditions can have a substantial effect on cuticle properties (Yeats et al. 2012).

The main health benefits correlated with the consumption of tomatoes (prevention of certain types of cancer, liver disorders, heart disease, osteoporosis, cataracts) are usually ascribed to the occurrence of lycopene and $\beta$-carotene, vitamins and potassium.
However, a number of pharmacological properties, such as antiallergic, antidepressant, antiinflammatory, antinociceptive, antipruritic, anxiolytic, gastroprotective and hepatoprotective activities of the amyrins (monohydroxy triterpene alcohols occurring in a variety of plant materials including tomato cuticular waxes) have been reported (Soldi et al. 2008; Melo et al. 2010; Ching et al. 2011). The mixture of amyrins employed in these studies was usually obtained from leaves or plant resins. If current research on potential pharmacological applications of amyrins produces promising results, it may be economically justified to devise methods to obtain these compounds from byproducts, like tomato peel, that remain after the annual processing of millions of tonnes of tomatoes into juice, ketchup, sauce, concentrate and other products.

\section{Other fruits with edible peel}

Edible berries of the genus Vaccinium, including lowbush blueberry $V$. angustifolium, rabbiteye blueberry $V$. ashei, highbush blueberry $V$. corymbosum, cranberry $V$. macrocarpon Ait., bilberry $V$. myrtillus L. and lingonberry (cowberry) V. vitis-idaea L. are valued for the high content of phenolic antioxidants and numerous health benefits ascribed to their consumption (Moyer et al. 2002; Ono et al. 2004; Neto 2007). Moreover, the occurrence of triterpenoids, mainly ursolic and oleanolic acids and their derivatives, is also well documented for some of these fruits (Murphy et al. 2003; He and Liu 2006; Szakiel and Mroczek 2007; Szakiel et al. 2007; Kondo et al. 2011, Szakiel et al. 2012). Cranberry, native to North America, has attracted public interest as a functional food preventing bacterial adhesion in urinary tract infections and stomach ulcers, protecting against lipoprotein oxidation, reducing cholesterol level and showing in vitro anticancer activity ( $\mathrm{He}$ and Liu 2006). Together with apple, pear, cherry and prune, cranberry cuticular wax is regarded as one of the richest natural sources of ursolic acid (Beindorff et al. 2001). As early as 1934, the wax extracted from cranberry pomace was shown to contain significant amounts of this compound and thus "crude ursolic acid" started to be produced commercially from a waste product of cranberry juice production. Later, more detailed study also revealed the presence of considerable amounts of oleanolic acid, methyl 


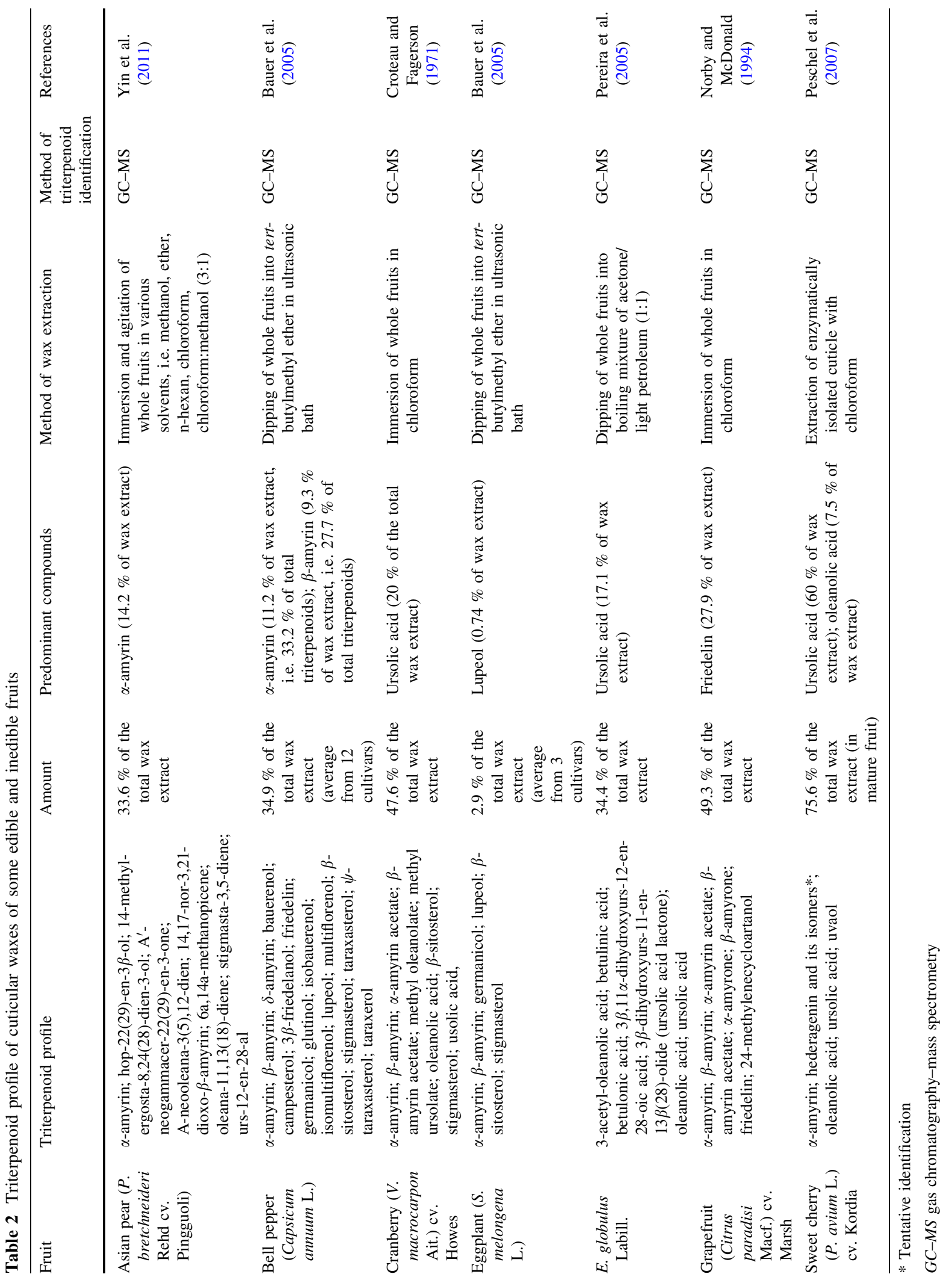


ursolate and methyl oleanolate, $\alpha$ - and $\beta$-amyrins and their acetates, as well as $\beta$-sitosterol and stigmasterol, altogether comprising $50 \%$ of a chloroform extract (Table 2). At that time, the highly complex composition of fruit cuticular wax, and especially the occurrence of several classes of triterpenoids with different ratios of ursane and oleanane skeletons in each of them, seemed somewhat unusual (Croteau and Fagerson 1971). Recently, two hydroxycinnamate esters of ursolic acid, occurring in ethyl acetate extracts from whole cranberry fruit and its products containing peel, were shown to possess antiproliferative activities against several types of tumor cells in vitro, including MCF-7 breast, HT-29 colon, DU-145 prostate, H460 lung, ME180 cervical and K562 leukemia cell lines. Cranberry juice and juice-derived sauce appear not to contain significant amounts of these compounds (Kondo et al. 2011; Neto 2011).

Ursolic acid is the predominat compound in the fruit cuticular wax of sweet cherry (Prunus avium L.). Studies on the composition of cuticular waxes during sweet cherry fruit development showed that triterpenoids represented the main class of wax constituents (75.6\% of total wax in mature fruit), with ursolic acid accounting for $60 \%$ and oleanolic acid for $7.5 \%$. Triterpene alcohols of the ursane type ( $\alpha$-amyrin and uvaol) were present in smaller amounts ( 0.4 and $0.8 \%$, respectively), and some other triterpenoids could not be identified by GC-MS due to their low abundance (Table 2). The initially very high level of triterpenoids in sweet cherry fruit cuticular wax (92.6\% at 22 days after full bloom), decreased by $18 \%$ at 85 days of fruit development to the level characteristic for the mature stage (Peschel et al. 2007). Thus, $P$. avium displays a pattern of cuticle development that resemble that of many other nonclimacteric fruits, which after depositing maximum levels of wax very early in fruit development, exhibit decreasing amounts of wax during ripening.

As shown for tomato, triterpene acids are not always present in fruit cuticular waxes. In Asian pear fruit (Pyrus bretchneideri Rehd), triterpenoids constituted $33.6 \%$ of the total wax, with $\alpha$-amyrin and urs12-en-28-al being the predominant compounds in a triterpenoid profile comprising 10 constituents (Table 2) (Yin et al. 2011). In bell pepper (Capsicum anиит L.), 18 triterpenoid compounds were identified (Table 2), accounting for $34.9 \%$ of the total wax extract, with $\alpha$-amyrin as the most abundant compound (33.2\% of total triterpenoids) followed by $\beta$-amyrin (27.7\%) (Bauer et al. 2005).

\section{Edible fruits with inedible peel}

Oranges, grapefruits, mandarines and other fruits of the genus Citrus L. are generally peeled when eaten fresh or consumed in the form of juice. Therefore, cuticular waxes of these fruits have been investigated not because of their nutritional value, but in relation to surface disorders like rindstaining, peel pitting or chilling injury, which can cause deterioration of fruit quality. Among cuticular constituents of orange $(C$. sinensis $\mathrm{L}$. Osbeck), tangerine (C. reticulata Blanco) and lemon $(C$. limon L. Burm.) harvested in central Florida, triterpenoids were found to constitute a minor fraction, with notable amounts of ursolic acid (Freeman et al. 1979). During fruit ripening, the triterpenoid content of total cuticular wax ranged between 3.3 and $9.4 \%$ in Satsuma mandarins growing in the area of Valencia, and between $3.3-8 \%$ and $3.7-13.6 \%$ in rindstaining-susceptible and non-susceptible Navelina oranges, respectively (Sala et al. 1992). Similarly, triterpenoids were a minor class of fruit cuticular wax component in Fortune mandarins $(C$. clementina $\times C$. reticulata $)$ grown in the same region, although their abundance in citrus fruits varied between cultivars and within the same cultivar grown in orchards in different geographical locations. Nevertheless, triterpenoids were never predominant compounds in any orange or mandarin cultivar (Sala 2000). In contrast, triterpenoids were found to be the most prevalent compounds in the fruit cuticular wax of grapefruit (C. paradisi Macf.), where they account for $50 \%$ of total wax. Furthermore, ursolic acid was not detected in grapefruit cuticular waxes, and the predominant compound was identified as the triterpene ketone,

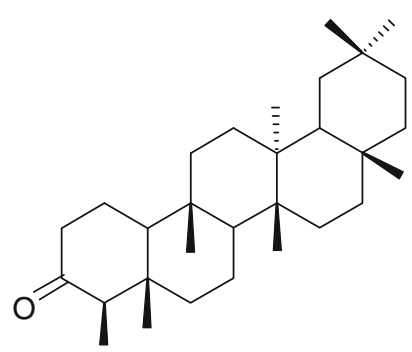

Fig. 5 Structure of friedelin occurring in fruit cuticular waxes of grapefruit (C. paradisi) 
friedelin (Norby and McDonald 1994). Friedelin (Fig. 5) was reported to be present in grapefruit peel as early as 1955 , and is probably the first triterpene ketone to be described in fruit cuticular wax. Recently, the biological properties of this compound, including antiinflammatory, analgestic and antipyretic activities, were investigated (Antonisamy et al. 2011). Other triterpenoids, including $\alpha$ - and $\beta$-amyrin, $\alpha$ - and $\beta$ amyrin acetate, the ketones: $\alpha$ - and $\beta$-amyrone, and 24-methylenecycloartanol (Table 2) were also detected in the fruit cuticular wax of Marsch grapefruit grown in central Florida (Norby and McDonald 1994). Lupeol and two other compounds, tentatively assigned as D:Bfriedo- $\mathrm{B}^{\prime}: \mathrm{A}^{\prime}$-neogammacer-5-en-ol and $\mathrm{D}: \mathrm{C}$-friedooleanen-3-one (another ketone), were subsequently added to this triterpenoid profile (Norby and McDonald 1995). Thus, grapefruit peel is characterized by particularly high levels of triterpenones (36\% of total wax).

Studies on fruits belonging to the genus Citrus have revealed that the chemical composition of cuticular wax can be very different regardless of systematic relationships. Likewise, the triterpenoid content in fruit cuticular waxes of the eggplant (Solanum melongena L.), which accounted for only $2.9 \%$ of the total wax extract, is surprisingly low compared with other members of the family Solanaceae, such as tomato and bell pepper (Bauer et al. 2005).

\section{Inedible fruits}

The tree Eucalyptus globulus Labill. is exploited for its wood, which is used by the pulp and paper industry, and for the essential oil extracted from the leaves. After harvesting the wood and leaves, large quantities of unwanted biomass, including the fruits, are discarded. Knowledge of the chemical composition of these unused plant parts could help to solve the problem of this waste material and increase the economic value of E. globulus cultivation. The cuticular wax of $E$. globulus fruit was shown to contain a significant amount of triterpenoids (34.4\% of the total wax extract), including ursolic acid, which accounted for $17.1 \%$ of total wax, and an interesting series of other triterpene acids, such as 3-acetyl-oleanolic acid, betulinic acid, betulonic acid, $3 \beta$-dihydroxyurs-11-en$13 \beta(28)$-olide (ursolic acid lactone), oleanolic acid and $3 \beta, 11 \alpha$-dihydroxyurs-12-en-28-oic acid (Table 2), the last of which was identified for the first time (Pereira et al. 2005). Betulinic acid, usually obtained from the bark of the white birch Betula alba L., has been shown to possess a variety of biological properties including antibacterial, anti-HIV, antimalarial, antiinflammatory and anthelmintic activities (Yogeeswari and Sriram 2005). Betulonic acid and its derivatives have been studied as a new group of agents that reduce the side effects of cytostatics (Sorokina et al. 2004; Vasilevsky et al. 2011). Therefore, the cuticular waxes of $E$. globulus fruit contain at least four biologically active triterpene acids (betulinic and betulonic, in addition to oleanolic and ursolic) that may be utilized rather than wasted.

\section{Concluding remarks}

Epidemiological studies have shown that regular consumption of fruit and vegetables is associated with a reduced risk of chronic diseases occurring in the aging human population. The health benefits of plant-based foods are attributed to bioactive phytochemicals, including triterpenoids and other groups of natural compounds, acting in an additive and synergistic way (Liu 2003). No single compound can replace the combination of various phytonutrients, playing their complementary or synergistic roles together. Fruits are a good example of such functional mixtures of water-soluble compounds, including many antioxidants occurring in the flesh, and lipophilic constituents of the cuticle.

Fruit cuticular waxes are receiving growing attention because they can have a significant influence on the production, storage and processing of agricultural commodities. Moreover, compositional studies on these waxes have revealed the occurrence of many biologically active triterpenoids, which, in several cases, accummulate to high concentrations, making the fruit peel an attractive and readily available source of these compounds.

Over the last decade, there has been a increasing interest in pharmaceutical, nutraceutical and cosmeceutical applications of triterpenoids, and they are currently under development as therapeutic agents in numerous treatments, and as functional compounds in many healthcare products. Triterpenoids are highly multifunctional and thus promising in the chemoprevention and chemotherapy of cancer and as antiparasitic agents. However, their activities have usually been demonstrated only in vitro, and although there are 
extensive preclinical data to support the supposed anticancer properties of triterpenoids, only clinical studies can fully validate them (Yadav et al. 2010). Due to the low polarity and consequently poor aqueous solubility of triterpenoids occurring in free and ester forms, their real bioavailability has been questioned (Jeong et al. 2007; Ganbold et al. 2010; Rada et al. 2011), and formulations based on nanotechnologies have been proposed to replace conventional dosage forms (Chen et al. 2011). At the same time, numerous triterpenoid derivatives with increased bioactivity and improved bioavailability have been synthesized by structural modifications of natural compounds (Bishayee et al. 2011; Sporn et al. 2011).

Since triterpenoids, both in their natural forms and as templates for synthetic modification, are currently of interest to both researchers and industry, natural sources supplying high concentrations of these compounds are in demand. Food industries produce large volumes of wastes, the disposal of which is problematic and may potentially cause environmental pollution. Millions of tonnes of apple, grape berry, olive, tomato, orange and other fruit peels are generated each year as agro-industrial waste which may be utilized to produce various useful materials, fuels and chemicals (Wolfe and Liu 2003; Zhang et al. 2004; Djilas et al. 2009; Ángel Siles López et al. 2010), including triterpenoid-containing products. Fruit pomace is often composted and used as a fertilizer, but sometimes (e.g. grape berry residues remaining after winemaking) it can have an adverse ecological impact due to the allelopathic activities of phenolic compounds inhibiting seed germination (Amico et al. 2004). As the human population grows and natural resources diminish, environmentally valuable and profitable technologies for obtaining natural basic compounds from available waste products are likely to become important for a sustainable future.

Open Access This article is distributed under the terms of the Creative Commons Attribution License which permits any use, distribution, and reproduction in any medium, provided the original author(s) and the source are credited.

\section{References}

Akihisa T, Ogihara J, Kato J et al (2001) Inhibitory effects of triterpenoids and sterols on human immunodeficiency virus-1 reverse transcriptase. Lipids 36:507-512
Ali K, Maltese F, Choi YH et al (2010) Metabolic constituents of grapevine and grape-derived products. Phytochem Rev 9:357-378

Amico V, Napoli EM, Renda A et al (2004) Constituents of grape pomace from the Sicilian cultivar 'Nerello Mascalese'. Food Chem 88:599-607

Ángel Siles López J, Li Q, Thompson IP (2010) Biorefinery of waste orange peel. Crit Rev Biotechnol 30:63-69

Antonisamy P, Duraipandiyan V, Ignacimuthu S (2011) Antiinflammatory, analgesic and antipyretic effects of friedelin isolated from Azima tetracantha Lam. in mouse and rat models. J Pharm Pharmacol 63:1070-1077

Aramon G, Saucier C, Tijou S et al (2003) Estimation of triterpenes in wines, spirits, and oak heartwoods by LC-MS. LCGC North Am 21:910-918

Awad AB, Fink CS (2000) Phytosterols as anticancer dietary components: evidence and mechanism of action. J Nutr 130:2127-2130

Bauer S, Schulte E, Thier H-P (2004a) Composition of the surface wax from tomatoes. I. Identification of the components by GC/MS. Eur Food Res Technol 219:223-228

Bauer S, Schulte E, Thier H-P (2004b) Composition of the surface wax from tomatoes. II. Quantification of the components at the ripe red stage and during ripening. Eur Food Res Technol 219:487-491

Bauer S, Schulte E, Thier H-P (2005) Composition of the surface waxes from bell pepper and eggplant. Eur Food Res Technol 220:5-10

Beindorff C, Cain FW, Pierce JH et al (2001) Blends of ursolic acid/oleanolic acid. US Patent 09/863,439, 24 May 2001

Belding RD, Blankenship SM, Young E et al (1998) Composition and variability of epicuticular waxes in apple cultivars. J Am Soc Hortic Sci 123:348-356

Belding RD, Sutton TB, Blankenship SM (2000) Relationship between apple fruit epicuticular wax and growth of $P e$ laster fructicola and Leptodontidium elatius, two fungi that cause sooty bloth disease. Plant Dis 84:767-772

Bianchi G, Murelli C, Vlahov G (1992) Surface waxes from olive fruits. Phytochemistry 31:3503-3506

Bianchi G, Pozzi N, Vlahov G (1994) Pentacyclic triterpene acids in olives. Phytochemistry 37:205-207

Bishayee A, Ahmed S, Brankov N et al (2011) Triterpenoids as potential agents for the prevention and therapy of breast cancer. Front Biosci 1(16):980-996

Bringe K, Schumacher CFA, Schmitz-Eiberger M (2006) Ontogenic variation in chemical and physical characteristics of adaxial apple leaf surfaces. Phytochemistry 67:161-170

Buschhaus C, Jetter R (2011) Composition differences between epicuticular and intracuticular wax substructures: how do plants seal their epidermal surfaces? J Exp Bot 62:841-853

Casado CG, Heredia A (1999) Structure and dynamics of reconstituted cuticular waxes of grape berry cuticle (Vitis vinifera L.). J Exp Bot 50:175-182

Casado CG, Heredia A (2001) Ultrastructure of the cuticle during growth of the grape berry (Vitis vinifera). Physiol Plant 111:220-224

Cefarelli G, D’Abrosca B, Fiorentino A et al (2006) Free-radical-scavenging and antioxidant activities of secondary metabolites from reddened cv. Annurca apple fruits. J Agric Food Chem 54:803-809 
Chen M, Zhong Z, Tan W et al (2011) Recent advances in nano particle formulation of oleanolic acid. Chin Med 6:20. doi: 10.1186/1749-8546-6-20

Ching J, Lin HS, Tan CH et al (2011) Quantification of $\alpha$ - and $\beta$ amyrin in rat plasma by gas chromatography-mass spectrometry: application to preclinic pharmacokinetic study. J Mass Spectrom 46:457-464

Comménil P, Brunet L, Audran JC (1997) The development of the grape berry cuticle in relation to susceptibility to bunch rot disease. J Exp Bot 48:1599-1607

Croteau R, Fagerson IS (1971) The chemical composition of the cuticular wax of cranberry. Phytochemistry 10:3239-3245

Dagna L, Gasparini G, Icardi ML et al (1982) Study of some components of the unsaponifiable fraction in the skin of grapes. Am J Enol Vitic 33:201-206

De Pablos LM, dos Santos MFB, Montero E (2010) Anticoccidial activity of maslinic acid against infection with Eimeria tenella in chickens. Parasitol Res 107:601-604

Djilas S, Čanadanovič-Brunet J, Četkovič G (2009) By-products of fruit processing as a source of phytochemicals. Chem Ind Chem Eng Quat 15:191-202

Dzubak P, Hajduch M, Vydra D et al (2006) Pharmacological activities of natural triterpenoids and their therapeutic implications. Nat Prod Rep 23:394-411

Ellgardt K (2006) Triterpenes in apple cuticle of organically and IP cultivated apples. Bachelor project in the DannishSwedish Horticulture Programme, ISSN 1652-1579, Dept of Crop Science, Sveriges Lantbruksuniversitet, Alnarp

Emmanuel E, Levy AA (2002) Tomato mutants as tools for functional genomics. Curr Opinion Plant Biol 5:112-117

Fernández-Bolaños J, Rodríguez G, Rodríguez R et al (2006) Extraction of interesting organic compounds from olive oil waste. Grasas Aceites 57:95-106

Fernández-Mar MI, Mateos R, Garcia-Parrilla MC et al (2011) Bioactive compounds in wine: resveratrol, hydroxytyrosol and melatonin: a review. Food Chem 130:797-813

Fernández-Navarro M, Peragón J, Esteban FJ et al (2006) Maslinic acid as a feed additive to stimulate growth and hepatic protein-turnover rates in rainbow trout (Onchorhynchus mykiss). Comp Biochem Physiol Part C 144:130-140

Frankel EN, Kannel J, German JB et al (1993) Inhibition of oxidation of human low-density lipoprotein by phenolic substances in red wine. Lancet 341:454-457

Freeman B, Albigo LG, Biggs RH (1979) Ultrastructure and chemistry of cuticular waxes of developing Citrus leaves and fruits. J Amer Soc Hortic Sci 104:801-808

Frighetto RTS, Welendorf RM, Nigro EN et al (2008) Isolation of ursolic acid from apple peels by high speed countercurrent chromatography. Food Chem 106:767-771

Gallo MBC, Sarachine MJ (2009) Biological activities of lupeol. Int J Biomed Pharm Sci 3(Special Issue 1):44-66

Ganbold M, Barker J, Ren M et al (2010) Cytotoxicity and bioavailability studies on a decoction of Oldenlandia diffus $a$ and its fractions separated by HPLC. J Ethnopharm 131:396-403

García A, Brenes M, Dobaranges MC et al (2008) Enrichment of pomace oil in triterpenic acids during storage of "Alpeorujo" olive paste. Eur J Lipid Sci Technol 110: 1136-1141

Glinsky J, Branly K (2001) Pentacyclic triterpenes. US Patent 09/207406, 16 October 2001
Guinda A, Rada M, Delgado T et al (2010) Pentacyclic triterpenoids from olive fruit and leaf. J Agric Food Chem 58:9685-9691

He X, Liu RH (2006) Cranberry phytochemicals: isolation, structure elucidation, and their antiproliferative and antioxidant activities. J Agric Food Chem 54:7069-7074

He X, Liu RH (2007) Triterpenoids isolated from apple peel have potent antiproliferative activity and may be partially responsible for apple's anticancer activity. J Agric Food Chem 55:4366-4370

Hill RA, Connolly JD (2011) Triterpenoids. Nat Prod Rep 28:1087-1117

Hooper L, Cassidy A (2006) A review of the health care potential of bioactive compounds. J Sci Food Agric 86:1805-1823

Iriti M, Faoro F (2009) Bioactivity of grape chemicals for human health. Nat Prod Commun 4:611-634

Jäger S, Trojan H, Kopp T et al (2009) Pentacyclic triterpene distribution in various plants-rich sources for a new group of multi-potent plant extracts. Molecules 14:2016-2031

Jeong DW, Kim YH, Kim HH et al (2007) Dose-linear pharmacokinetics of oleanolic acid after intravenous and oral administration in rats. Biopharm Drug Dispos 28:51-57

Jetter R, Schäffer S (2001) Chemical composition of the Prunus laurocerasus leaf surface. Dynamic changes of the epicuticular wax film during leaf development. Plant Physiol 126:1725-1737

Jetter R, Schäffer S, Riederer M (2000) Leaf cuticular waxes are arranged in chemically and mechanically distinct layers: evidence from Prunus laurocerasus L. Plant, Cell Environ 23:619-628

Juan ME, Planas JM (2010) Effects of pentacyclic triterpenes from olives on colon cancer. In: Watson RR, Preedy VR (eds) Bioactive food and extracts. CRC Press, Boka Raton, pp 403-413

Juan ME, Wenzel U, Ruiz-Gutierrez V et al (2006) Olive fruit extracts inhibit proliferation and induce apoptosis in HT-29 colon cancer cells. J Nutr 136:2553-2557

Juan ME, Planas JM, Ruiz-Gutierrez V et al (2008) Antiproliferative and apoptosis-inducing effects of maslinic and oleanolic acids, two pentacyclic triterpenes from olives, on HT-29 colon cancer cells. Brit J Nutr 100:36-43

Kondo M, MacKinnon SL, Craft CC et al (2011) Ursolic acid and its esters: occurrence in cranberries and other Vaccinium fruit and effects on matrix metalloproteinase activity in DU145 prostate tumor cells. J Sci Food Agric 91:789-796

Kosma DK, Parsons EP, Isaacson T (2010) Fruit cuticle lipid composition during development in tomato ripening mutants. Physiol Plant 139:107-117

Kuo RY, Quian K, Morris-Natschke SL et al (2009) Plantderived triterpenes and analogues as antitumor and antiHIV agents. Nat Prod Rep 26:1321-1344

Laszczyk MN (2009) Pentacyclic triterpenes of the lupane, oleanane and ursane group as tools in cancer therapy. Planta Med 75:1549-1560

Le Fur Y, Hory C, Bard MH et al (1994) Evolution of phytosterols in Chardonnay grape berry skins during last stages of ripening. Vitis 33:127-131

Leide J, Hildebrandt U, Reussing K et al (2007) The developmental pattern of tomato fruit wax accumulation and its 
impact on cuticular transpiration barrier properties: effects of a deficiency in a $\beta$-ketoacyl-coenzyme A synthase (LeCER6). Plant Physiol 144:1667-1679

Leide J, Hildebrandt U, Vogg G et al (2011) The positional sterile (ps) mutation affects cuticular transpiration and wax biosynthesis of tomato fruits. J Plant Physiol 168:871-877

Leifert WR, Abeywardena MY (2008) Cardioprotective actions of grape polyphenols. Nutr Res 28:729-737

Liu RH (2003) Health benefits of fruits and vegetables are from additive and synergistic combination of phytochemicals. Am J Clin Nutr 78:517S-520S

Liu J (2005) Oleanolic acid and ursolic acid: research perspectives. J Ethnopharm 100:92-94

Liu T, Ma L, Zhao J et al (2007) Protective effects of triterpenoids from Vitis vinifera L. on immunological liver injury in vitro. J Xinjiang Med Univers 30:1222-1225

Liu T, Zhao J, Li H et al (2010) Evaluation on anti-hepatitis viral activity of Vitis vinifera L. Molecules 15:7415-7421

Liu J, Sun H, Shang J et al (2011) Effect of olive pomace extracts on hyperlipidaemia. Nat Prod Res 25:1190-1194

Ma CM, Cai SQ, Cui JR et al (2005) The cytotoxic activity of ursolic acid derivatives. Eur J Med Chem 40:582-589

Marchal A, Waffo-Teguo P, Genin E, Merillon JM, Dubourdieu D (2011) Identification of new natural sweet compounds in wine using centrifugal partition chromatography-gustatometry and Fourier transform mass spectrometry. Anal Chem 83:9629-9637

Martín R, Ibeas E, Carvalho-Tavares J et al (2009) Natural triterpenic diols promote apoptosis in astrocytoma cells through ROS-mediated mitochondrial depolarization and JNK activation. PLoS ONE 4:e5975. doi:10.1371/journal. pone. 0005975

Martín R, Carvalho-Tavares J, Hernández M et al (2010) Beneficial effects of oleanolic acid in an experimental model of multiple sclerosis: a potential therapeutic role. Biochem Pharmacol 79:198-208

McGhie TK, Hudault S, Lunken RCM, Christeller JT (2012) Apple peels, from seven cultivars, have lipase-inhibitory activity and contain numerous ursenoic acids as identified by LC-ESI-QTOF-HRMS. J Agric Food Chem 60: 482-491

Melo C, Carvalho KMMB, de Sousa Neves JC et al (2010) $\alpha$, $\beta$-Amyrin, a natural triterpenoid ameliorates L-arginineinduced acute pancreatitis in rats. World J Gastroenterol $14: 4272-4280$

Mintz-Oron S, Mandel T, Rogachev I et al (2008) Gene expression and metabolism in tomato fruit surface tissues. Plant Physiol 147:823-851

Moneriz C, Mestres J, Bautista JM et al (2011) Multi-targeted activity of maslinic acid as an antimalarial natural compound. FEBS J 16:2951-2961

Moyer RA, Hummer KE, Finn CE et al (2002) Anthocyanins, phenolics and antioxidant capacity in diverse small fruits: Vaccinium, Rubus and Ribes. J Agric Food Chem 50: 519-525

Müller C, Riederer M (2005) Plant surface properties in chemical ecology. J Chem Ecol 31:2621-2651

Murphy BT, MacKinnon SL, Yan X et al (2003) Identification of triterpene hydroxycinnamates with in vitro antitumor activity from whole cranberry fruit (Vaccinium macrocarpon). J Agric Food Chem 51:3541-3545
Neto CC (2007) Cranberry and blueberry: evidence for protective effects against cancer and vascular diseases. Mol Nutr Food Res 51:652-664

Neto CC (2011) Ursolic acid and other pentacyclic triterpenoids: anticancer activities and occurrence in berries. In: Stoner GD, Seeram NP (eds) Berries and cancer prevention. Springer, LLC, pp 41-49

Niaounakis M, Halvadakis CP (2006) Olive processing waste management: literature review and patent survey. Elsevier Ltd, London

Norby HE, McDonald RE (1994) Friedelin, the major component of grapefruit epicuticular wax. J Agric Food Chem 42:708-713

Norby HE, McDonald RE (1995) Variations in chilling injury and epicuticular wax composition of white grapefruit with canopy position and fruit development during the season. J Agric Food Chem 43:1828-1833

Ono M, Koto M, Komatsu H et al (2004) Cytotoxic triterpenes and sterol from the fruit of rabbiteye blueberry (Vaccinium ashei). Food Sci Technol Res 10:56-59

Orbán N, Kozák IO, Drávucz M et al (2009) LC-MS method development to evaluate major triterpenes in skins and cuticular waxes of grape berries. Int J Food Sci Tech 44:869-873

Ortega RM (2006) Importance of functional foods in the Mediterranean diet. Public Health Nutr 9:1136-1140

Owen RW, Haubner R, Wurtele G et al (2004) Olives and olive oil in cancer prevention. Eur J Cancer Prev 13:319-326

Patočka J (2003) Biologically active pentacyclic triterpenes and their current medicine signification. J Appl Biomed 1:7-12

Pereira SI, Freire CSR, Neto CP et al (2005) Chemical composition of the epicuticular wax from the fruits of Eucalyptus globulus. Phytochem Anal 16:364-369

Pérez-Camino MC, Cert A (1999) Quantitative determination of hydroxyl pentacyclic triterpene acids in vegetable oils. J Agric Food Chem 47:1558-1562

Peschel S, Franke R, Schreiber L et al (2007) Composition of the cuticle of developing sweet cherry fruit. Phytochemistry 68:1017-1025

Petronelli A, Pannitteri G, Testa U (2009) Triterpenoids as new promising anticancer drugs. Anticancer Drugs 20:880-892

Piironen V, Lindsay DG, Miettinen TA et al (2000) Plant sterols: biosynthesis, biological function and their importance to human nutrition. J Sci Food Agric 80:939-966

Rada M, Ruiz-Gutiérrez V, Guinda A (2011) Determination of triterpenic acid in human serum by high-performance liquid chromatography: triterpenoid interaction with serum protein. J Agric Food Chem 59:2308-2313

Radler F (1965a) The surface waxes of the sultana vine (Vitis vinifera $\mathrm{cv}$. Thompson seedless). Aust J Chem 18:10451056

Radler F (1965b) The main constituents of the surface waxes of varieties and species of genus VITIS. Am J Enol Vitic 16:159-167

Radler F, Horn DHS (1965) The composition of grape cuticle wax. Aust J Chem 18:1059-1069

Rezanka T, Siristova L, Sigler K (2009) Sterols and triterpenoids with antiviral activity. Anti Infect Agents Med Chem 8:193-210

Rivero-Cruz JF, Zhu M, Kinghorn AD et al (2008) Antimicrobial constituents of Thompson seedless raisins (Vitis 
vinifera) against selected oral pathogens. Phyt Lett $1: 151-154$

Rodriguez-Rodriguez R, Perona JS, Herrera MD, Ruiz-Gutierrez V (2006) Triterpenic compounds from "orujo" olive oil elicit vasorelaxation in aorta from spontaneously hypertensive rats. J Agric Food Chem 54:2096-2102

Romero C, García A, Medina E (2010) Triterpenic acids in table olives. Food Chem 118:670-674

Rudell DR, Mattheis JP, Hertog MLATM (2009) Metabolomic change precedes apple superficial scald symptoms. J Agric Food Chem 57:8459-8466

Sala JM (2000) Content, chemical composition and morphology of epicuticular wax of Fortune mandarin fruits in relation to peel pitting. J Sci Food Agric 80:1887-1894

Sala JM, Lafuente T, Cuñat P (1992) Content and chemical composition of epicuticular wax of 'Navelina' oranges and 'Satsuma' mandarins as related to rindstaining of fruit. J Sci Food Agric 59:489-495

Shishodia S, Majumdar S, Banerjee S, Aggarwal BB (2003) Ursolic acid inhibits nuclear factor- $\kappa \mathrm{B}$ activation induced by carcinogenic agents through suppression of $\mathrm{I} \kappa \mathrm{B} \alpha$ kinase and $\mathrm{p} 65$ phosphorylation: correlation with down-regulation of cyclooxygenase 2, matrix metalloproteinase 9, and cyclin D1. Cancer Res 63:4375-4383

Soldi C, Pizzolatti MG, Luiz AP et al (2008) Synthetic derivatives of the $\alpha$ - and $\beta$-amyrin triterpenes and their antinociceptive properties. Bioorg Med Chem 16:3377-3386

Sorokina IV, Tolstikova TG, Zhukova NA et al (2004) Betulonic acid and derivatives, a new group of agents reducing side effects of cytostatics. Doklady Biol Sci 399:434-437

Sporn MB, Liby KT, Yore MM et al (2011) New synthetic triterpenoids: potent agents for prevention and treatment of tissue injury caused by inflammatory and oxidative stress. J Nat Prod 74:537-545

Stiti N, Hartmann MA (2012) Nonsterol triterpenoids as major constituents of Olea europaea. J Lipids. doi:10.1155/2012/ 476595

Stiti N, Triki S, Hartmann MA (2007) Formation of triterpenoids throughout Olea europaea fruit ontogeny. Lipids 42:55-67

Sun H, Fang WS, Wang WZ et al (2006) Structure-activity relationship of oleanane- and ursane-type triterpenoids. Bot Studies 47:339-368

Szakiel A, Mroczek A (2007) Distribution of triterpene acids and their derivatives in organs of cowberry (Vaccinium vitis-idaea L.) plant. Acta Biochim Polon 54:733-740

Szakiel A, Chołuj A, Paczkowski C (2007) Comparison of the content of triterpene acids in edible berries of three wild Vaccinium species occurring in Poland. Acta Biochim Polon 54(Suppl.4):77

Szakiel A, Pączkowski C, Koivuniemi H, Huttunen S (2012) Comparison of the triterpenoid content of berries and leaves of lingonberry Vaccinium vitis-idaea from Finland and Poland. J Agric Food Chem 60:4994-5002

Thoppil RJ, Bishayee A (2011) Terpenoids as potential chemopreventive and therapeutic agents in liver cancer. World J Hepatol 27:228-249

Vasilevsky SF, Gavdi AI, Sorokina IV et al (2011) Rapid access to new bioconjugates of betulonic acid via click chemistry. Bioorg Med Chem Lett 21:62-65
Verardo G, Pagani E, Geatti P et al (2003) A thorough study of the surface wax of apple fruits. Anal Bioanal Chem 376:659-667

Villasenor IM, Angelada J, Canlas AP et al (2002) Bioactivity studies on $\beta$-sitosterol and its glucoside. Phytother Res 16:417-421

Vioque E, Maza MP (1963) On triterpenic acids from olive and olive pomace oils. Grasas Aceites 14:9-11

Vislocky LM, Fernandez ML (2010) Biomedical effects of grape products. Nutr Rev 68:656-670

Vogg G, Fischer S, Leide J et al (2004) Tomato fruit cuticular waxes and their effects on transpiration barrier properties: functional characterization of a mutant deficient in a verylong-chain fatty acid $\beta$-ketoacyl-CoA synthase. J Exp Bot 55:1401-1410

Wang Z, Guhling O, Yao R et al (2011) Two oxidosqualene cyclases responsible for biosynthesis of tomato fruit cuticular triterpenoids. Plant Physiol 155:540-552

Willet WC (1994) Diet and health: what should we eat? Science 264:532-537

Wolfe KL, Liu RH (2003) Apple peels as a value-added food ingredient. J Agric Food Chem 51:1676-1683

Wolfe KL, Wu XZ, Liu RH (2003) Antioxidant activity of apple peels. J Agric Food Chem 51:609-614

Wolska KI, Grudniak AM, Fiecek B et al (2010) Antibacterial activity of oleanolic and ursolic acids and their derivatives. Cent Eur J Biol 5:543-553

World Health Statistics Annual (1989) World Health Organization, Geneva, ISBN 13: 9789240678903

Wu CD (2009) Grape products and oral health. J Nutr 39:S1818-S1823

Yadav M, Jain S, Bhardavi A et al (2009) Biological and medicinal properties of grapes and their bioactive constituents: an update. J Med Food 12:473-484

Yadav VR, Prasad S, Sung B et al (2010) Targeting inflammatory pathways by triterpenoids for prevention and treatment of cancer. Toxins 2:2428-2466

Yamaguchi H, Noshita T, Kidachi Y et al (2008) Isolation of ursolic acid from apple peels and its specific efficacy as a potent antitumor agent. J Health Sci 54:654-660

Yamamura H, Naito R (1983) The surface wax of several grapes in Japan. J Jap Soc Hortic Sci 52:266-272

Yeats TH, Buda GJ, Wang Z et al (2012) The fruit cuticles of wild tomato species exhibit architectural and chemical diversity, providing a new model for studying the evolution of cuticle function. Plant J 69:655-666

Yeung MF, Che CT (2009) Literature review on pharmaceutical activities of oleanolic acid. Nat Proda Med 2:291-298

Yin Y, Bi Y, Chen S et al (2011) Chemical composition and antifungal activity of cuticular wax isolated from Asian pear fruit (cv. Pingguoli). Sci Hortic 129:577-582

Yogeeswari P, Sriram D (2005) Betulinic acid and its derivatives: a review on their biological properties. Curr Med Chem 12:657-666

Zhang Y, Jayaprakasam B, Seeram NP (2004) Insulin secretion and cyclooxygenase enzyme inhibition by Cabernet Sauvignon grape skin compounds. J Agric Food Chem 52:228-233 